\title{
Synthesis Characterization and Biological Activity Study of New Schiff and Mannich Bases and Some Metal Complexes Derived from Isatin and Dithiooxamide
}

\author{
Ahlam J. Abdulghani and Nada M. Abbas \\ Department of Chemistry, College of Science, University of Baghdad, Jaderiya, Baghdad, Iraq \\ Correspondence should be addressed to Ahlam J. Abdulghani, prophahlam@yahoo.com \\ Received 6 December 2010; Revised 5 February 2011; Accepted 27 February 2011 \\ Academic Editor: Zhe-Sheng Chen
}

Copyright ( 2011 A. J. Abdulghani and N. M. Abbas. This is an open access article distributed under the Creative Commons Attribution License, which permits unrestricted use, distribution, and reproduction in any medium, provided the original work is properly cited.

Two new Schiff and Mannich bases, namely, 1-Morpholinomethyl-3(1'-N-dithiooxamide)iminoisatin $\left(\mathrm{L}_{\mathrm{I}} \mathrm{H}\right)$ and 1-diphenylaminomethyl-3-1'-N-dithiooxamide)iminoisatin $\left(\mathrm{L}_{\mathrm{II}} \mathrm{H}\right)$, were prepared from condensation reaction of new Schiff base 3-(1'-Ndithiooxamide)iminoisatin (SBH) with morpholine or diphenylamine respectively in presence of formaldehyde. The structures were characterized by IR, ${ }^{1} \mathrm{HNMR}$, mass spectrometry, and CHN analyses. Metal complexes of the two ligands were synthesized, and their structures were characterized by elemental analyses, atomic absorption, IR and UV-visible spectra, molar conductivity, and magnetic moment determination. All complexes showed octahedral geometries except palladium complexes which were square planar. The biological activity of the prepared compounds and some selected metal complexes was tested against three types of bacteria and against cell line of human epidermoid larynx carcinoma (Hep-2).

\section{Introduction}

Various Mannich Schiff bases of isatin have been found to be of biological importance [1] and have shown anticonvulsant [2], antibacterial [3, 4], antimicrobial [5-7] and anti-HIV activities [8, 9]. Dithiooxamide (dto) is an effective flexidentate complexing agent with varied coordination chemistry. Due to the intense chromophoric character, dto can be used in an imaging processes [10], coordination polymers [11], histological agents, and as a source for duplicating processes [12]. The transition metal complexes of dto and its derivatives are characterized by semiconductor, magnetic, and spectroscopic properties [12-15]. The aim of this work is to synthesize and study the coordination behavior of the two new Schiff and Mannich base ligands $\mathrm{L}_{\mathrm{I}} \mathrm{H}$ and $\mathrm{L}_{\mathrm{II}} \mathrm{H}$ shown in Scheme 1, from condensation reaction of a new Schiff base 3( $1^{\prime}$-N-dithiooxamide) iminoisatin $(\mathrm{SBH})$ with morpholine or diphenylamine, respectively, in presence of formaldehyde in a mole ratio of $(1: 1: 1)$, respectively, or from reaction of Mannich bases $\mathrm{N}$-morpholinomethyl isatin $\left(\mathrm{M}_{\mathrm{I}}\right)$ and $\mathrm{N}$ diphenylaminomethyl isatin $\left(\mathrm{M}_{\mathrm{II}}\right)$ [16] with dithiooxamide.
The biological activity of the two ligands and some of their metal complexes was investigated against selected types of bacteria and against cancer cell line of human epidermoid larynx carcinoma (Hep-2).

\section{Experimental/Materials and Methods}

Melting points (uncorrected) were determined by using Gallenkamp MFB600-010f m.p apparatus. The purity of the synthesized compounds was checked by T.L.C. techniques using a mixture of chloroform and acetone $(2: 2 \mathrm{~V} / \mathrm{V})$ and various ratios of methyl acetate: acetone solvent mixture as eluents and iodine chamber for spot location. The HPLC of the Schiff base $(\mathrm{SBH})$ and the derived two ligands were obtained by using HPLC (LKB), mobile phase $\mathrm{CH}_{3} \mathrm{CN}: \mathrm{H}_{2} \mathrm{O}$ $(80: 20)$. Infrared spectra were recorded on a Perkin-Elmer 1310 IR spectrophotometer and Shimadzu corporation 20091527 IR spectrophotometer using $\mathrm{KBr}$ and CsI disks. ${ }^{1} \mathrm{H}$ n.m.r spectra of the organic compounds were recorded on a $300 \mathrm{MHz}$ n.m.r spectrophotometer (Joel) using TMS as internal reference. Mass spectra were recorded on a Joel 700 
mass spectrometer. Elemental CHN analyses were obtained by using EA elemental analyzer (Fison Ision Instrument). Electronic spectra of the ligands and their metal complexes in the region $200-1100 \mathrm{~nm}$ were recorded on a Shimadzu UV-visible-160 spectrophotometer. The metal contents were determined by atomic absorption technique using a VarianAA-775 atomic absorption instrument. Electrical conductivity of metal complexes was measured at room temperature in DMF $\left(10^{-3} \mathrm{M}\right)$ using Elkta Lictfahigkeit conductivity meter (SIMENS). Magnetic moments ( $\left.\mu_{\text {eff }} \mathrm{BM}\right)$ for the solid metal complexes at room temperature were determined according to Faraday's method by using Johnson Mattey magnetic balance system division. Chloride content of metal complexes was determined by potentiometric titration using 1686titroprocessor-665 Dosinametrom (Swiss). All organic and inorganic materials were of high purity and used as received except ethanol, methanol, and DMF which were dried and distilled prior to use [17]. Palladium(II) chloride was converted to dichlorobis(benzonitrile)palladium(II) [18], and $\mathrm{H}_{2} \mathrm{PtCl}_{6} \cdot 6 \mathrm{H}_{2} \mathrm{O}$ was converted to potassium hexachloroplatinate(IV) hexahydrate [19] prior to use. Mannich bases Nmorpholinomethylisatin $\left(\mathrm{M}_{\mathrm{I}}\right)$ and $\mathrm{N}$-diphenylaminomethyl isatin $\left(\mathrm{M}_{\mathrm{II}}\right)$ were prepared according to methods mentioned in the literature [16]. Complex formation was studied in solutions to obtain the molar ratio of the ligand to metal ion (L:M) using ethanol, or DMSO as solvents. A series of solutions containing constant concentration of the metal ion $\left(1 \times 10^{-4} \mathrm{M}\right)$ were treated with various amounts of the same concentration of the ligand. The results of $(\mathrm{L}: \mathrm{M})$ ratio were obtained by plotting absorbance of solution mixtures at detected $\lambda_{\max }$ against [L]/[M].

\section{Preparation of Ligands}

3.1. 3-(1'-N-dithiooxamide)iminoisatin (SBH). A solution mixture of isatin $(0.01$ mole, $1.47 \mathrm{~g})$ and dto $(0.01$ mole, $1.021 \mathrm{~g})$ in dry ethanol $(50 \mathrm{~mL})$ containing $2-3$ drops glacial acetic acid was heated under reflux for $8 \mathrm{~h}$ with continuous stirring. The mixture was then left at room temperature for $24 \mathrm{hs}$. A yellow precipitate was formed. The product was filtered, washed with warm ethanol, and crystallized from ethanol:dichloromethane solvent mixture $(1: 1)$. m.p. $190^{\circ} \mathrm{C}$ yield 60\%; IR (KBr) $v\left(\mathrm{~cm}^{-1}\right)$ : 3296, $3203\left(\mathrm{NH}_{2}\right) ; 3147(\mathrm{NH}-$ isatin); $1733(\mathrm{C}=\mathrm{O}), 1614(-\mathrm{C}=\mathrm{N}) ; 1540(\mathrm{C}-\mathrm{S}+\delta \mathrm{NH}, \mathrm{I})$; $1430(\mathrm{C}-\mathrm{N}+\mathrm{C}-\mathrm{S}, \mathrm{II}) ; 1197(\mathrm{C}-\mathrm{S}, \mathrm{III}) ; 835(\mathrm{C}=\mathrm{S}, \mathrm{IV}) .{ }^{1} \mathrm{H}$ n.m.r. $\delta(\mathrm{ppm})\left(\mathrm{CD}_{2} \mathrm{Cl}_{2}\right) 12.012(1 \mathrm{H}, \mathrm{s}, \mathrm{NH}) ; 7.653-6.94$ $\left(4 \mathrm{H}, \mathrm{m}\right.$, aromatic); $2.022\left(2 \mathrm{H}, \mathrm{d}, \mathrm{NH}_{2}\right) . \mathrm{MS},(\mathrm{m} / \mathrm{z})(\mathrm{I} \%)$ (EI) calculated for $\mathrm{C}_{10} \mathrm{H}_{7} \mathrm{~N}_{3} \mathrm{OS}_{2}$ m.wt $249 \mathrm{~g} /$ mole: 250 (10) $[\mathrm{M}+1] ; 221$ (3.2) [M-CO]; 207 (4) [M-NCO]; $162(2) ; 119$ (24); 90 (7.5).

\subsection{1-Morpholinomethyl-3-(1'-N-dithiooxamide)iminoisatin} $\left(L_{I} H\right)$ and 1-diphenylaminomethyl-3-1'-N-dithiooxamide) Iminoisatin $\left(L_{I I} H\right)$. (a) To a stirred solution of $3-\left(1^{\prime}-\mathrm{N}-\right.$ dithiooxamide)iminoisatin (SBH) (0.01 mole, $2.49 \mathrm{~g})$ and formaldehyde $37 \%(0.015$ mole $)$ in warm dry ethanol $(20 \mathrm{~mL})$ was added, drop by drop, (0.01 mole) of morpholine $\left(\mathrm{L}_{\mathrm{I}} \mathrm{H}\right)$ or diphenylamine $\left(\mathrm{L}_{I I} \mathrm{H}\right)$. The mixture was heated

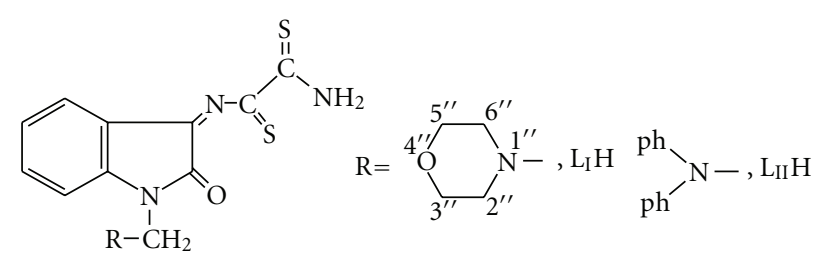

Scheme 1: The structures of the prepared ligands.

under reflux for $3 \mathrm{~h}$ with continuous stirring, and then left to cool at room temperature. A solid precipitate was formed. The products were filtered, washed with warm ethanol, and then crystallized from ethanol:chloroform $(1: 1 \mathrm{v} / \mathrm{v})$ mixture; yield 35 and $28.2 \%$, respectively.

(b) To a solution of dto ( 5 mmole, $0.6 \mathrm{~g})$ in warm ethanol $(10 \mathrm{~mL})$ containing 2-3 drops glacial acetic acid was added (5 mmole) of Mannich base N-Morpholinomethylisatin $\left(\mathrm{M}_{\mathrm{I}}\right)$ or N-Diphenylaminomethyl isatin $\left(\mathrm{M}_{\mathrm{II}}\right)$ [16] in ethanol $(10 \mathrm{~mL})$ with continuous stirring, and the mixture was heated under reflux for $10 \mathrm{~h}$. After leaving the mixture at room temperature for $24 \mathrm{~h}$ a precipitate was formed. The products were filtered, washed with warm ethanol, and crystallized; yield 20.3 and 21\%, respectively (m.p. 215 and $283^{\circ} \mathrm{C}$, resp.).

1-Morpholinomethyle-3-(1'-N-dithiooxamide) iminoisatin $\left(L_{I} H\right)$ : yellowish orange crystals, m.p. $162^{\circ} \mathrm{C}$; IR $(\mathrm{KBr})$. $\nu\left(\mathrm{cm}^{-1}\right)$ : 3203, $3138\left(\mathrm{NH}_{2}\right)$; 3030-3000 (arom CH); 2815$2364\left(\mathrm{CH}_{2}\right) ; 1730(\mathrm{C}=\mathrm{O}) ; 1614(-\mathrm{C}=\mathrm{N}) ; 1589(\mathrm{C}=\mathrm{C}$ arom. $)$; $1540(\nu \mathrm{C}=\mathrm{N}, \delta \mathrm{NH}, \mathrm{I}) ; 1429(\mathrm{C}-\mathrm{N}+\mathrm{C}-\mathrm{S}, \mathrm{II}) ; 1195(\mathrm{C}-\mathrm{S}, \mathrm{III})$; 835 (C=S, IV); 1149, 1328 (morpholine). ${ }^{1} \mathrm{H}$ n.m.r $\delta(\mathrm{ppm})$ (DMSO): 7.59-6.898 $(4 \mathrm{H}, \mathrm{m}$, aromatic $+\mathrm{NH}) ; 4.09(2 \mathrm{H}$, d, $\left.\mathrm{N}-\mathrm{CH}_{2} \mathrm{~N}\right) ; 3.65\left(4 \mathrm{H}, \mathrm{d}, 2^{\prime \prime}, 6^{\prime \prime} \mathrm{CH}_{2}\right.$ morph.); $2.33(4 \mathrm{H}$, d, 3", 5" $\mathrm{CH}_{2}$ morph.); 1.567 (1H, br, SH). MS (FAB) m/z (I\%) calculated for $\mathrm{C}_{15} \mathrm{H}_{16} \mathrm{~N}_{4} \mathrm{O}_{2} \mathrm{~S}_{2}$, m.wt $348.45 \mathrm{~g} / \mathrm{mole}$,: 349.1 (93) [M]; 320 (38) [M-CO]; 235 (100); 234 (80); 220 (15), 207 (40). 131 (43); 104 (78\%); (EI) m/z (I\%): 348.5 (84) $[\mathrm{M}] ; 320$ (25) [M-CO]; 234 (38); 207 (17); 130 (19); 117 (24); 104 (57); 90 (30); 78 (22\%). CHN\% Calculated for $\mathrm{C}_{15} \mathrm{H}_{16} \mathrm{~N}_{4} \mathrm{O}_{2} \mathrm{~S}_{2} \mathrm{C}, 51.67 ; \mathrm{H}, 4.59, \mathrm{~N}, 16.07 \%$ found $\mathrm{C}, 50.69$; $\mathrm{H}, 4.20 ; \mathrm{N}, 15.75 \% ; v_{\max }\left(\mathrm{cm}^{-1}\right)(\mathrm{DMF})\left(\varepsilon_{\max } \mathrm{mol}^{-1} \mathrm{~cm}^{-1}\right)$ 34013 (20030) $\pi \rightarrow \pi^{*} ; 2415$ (2980), $n \rightarrow \pi^{*}$ (DMSO) 38461 (19519) $\pi \rightarrow \pi^{*}$.

Diphenylaminomethyl-3- $\left(1^{\prime}-N\right.$-dithiooxamide $)$ Iminoisatin $\left(L_{I I} H\right)$ : yellow red crystals, m.p. 182, IR $(\mathrm{KBr}) \nu\left(\mathrm{cm}^{-1}\right)$ : 3193, $3034\left(\mathrm{NH}_{2}\right) ; 1730(\mathrm{C}=\mathrm{O}) ; 1614(\mathrm{C}=\mathrm{N}) ; 1540,1434$, $1195,833(\mathrm{C}-\mathrm{N}+\delta \mathrm{NH}, \mathrm{C}-\mathrm{N}+\mathrm{C}-\mathrm{S}, \mathrm{C}-\mathrm{S}, \mathrm{C}=\mathrm{S} \mathrm{I}-\mathrm{IV}, \mathrm{resp}$.$) .$ ${ }^{1} \mathrm{H}$ n.m.r $(\delta, \mathrm{ppm})\left(\mathrm{CD}_{2} \mathrm{Cl}_{2}\right): 7.59-6.89(14 \mathrm{H}, \mathrm{m}$, aromatic); $4.83\left(2 \mathrm{H}, \mathrm{d}, \mathrm{CH}_{2}\right) ; 2.17\left(2 \mathrm{H}, \mathrm{b}, \mathrm{NH}_{2}\right) . \mathrm{MS} \mathrm{m} / \mathrm{z}(\mathrm{I} \%)(\mathrm{EI})$ : calculated for $\mathrm{C}_{23} \mathrm{H}_{18} \mathrm{~N}_{4} \mathrm{OS}_{2}$, m.wt $430.55 \mathrm{~g} / \mathrm{mol}: 430.9$ (5.5) [M]; 402 (2.5) [M-CO]; 235 (21); 129.2 (1.8); 104 (4.8); 89 (10.3); 78.1 (3.5\%). CHN (\%) calculated for $\mathrm{C}_{23} \mathrm{H}_{18} \mathrm{~N}_{4} \mathrm{OS}_{2}$ : C, 64.18, H, 4.21; N, 13.02\% found: C, 64.02; H, 4.22; N, $13.52 \%$. $v_{\max }\left(\mathrm{cm}^{-1}\right)(\mathrm{DMF})\left(\varepsilon_{\max }, \mathrm{L} \mathrm{mol} \mathrm{mol}^{-1} \mathrm{~cm}^{-1}\right) 32258$ (22970) $\pi \rightarrow \pi^{*}$; 24509 (3530) $n \rightarrow \pi^{*}$; (DMSO): 38461 (19540): 28571 (14120) $\pi \rightarrow \pi^{*}$. 
(A)

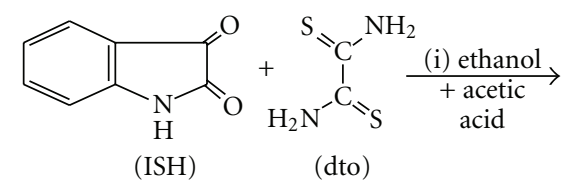<smiles></smiles>

$(\mathrm{SBH})$<smiles>[13CH3]</smiles>
morpholine or , N-diphenylamine,

(B)

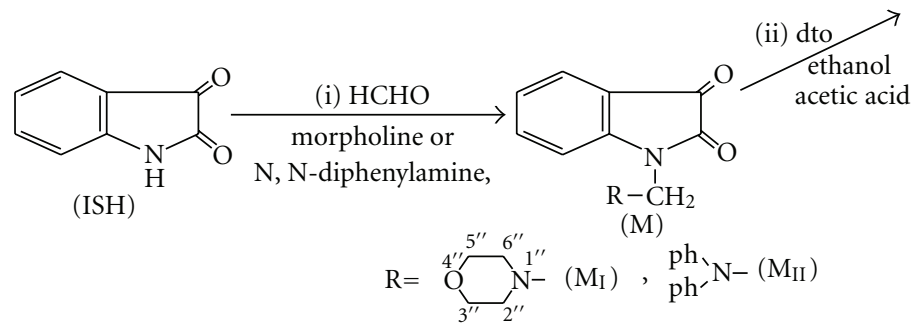<smiles>NC(=S)C(=S)N=C(CS)NC(=O)c1ccccc1</smiles>
$\mathrm{R}-\stackrel{\mathrm{C}}{\mathrm{CH}} \mathrm{H}_{2}$ $\mathrm{R}=$

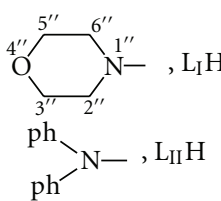
Scheme 2: Synthesis of Schiff Mannich base ligands from isatin and dithiooxamide.

\section{Synthesis of Metal Complexes}

To a solution of Schiff Mannich base ligand ( 2 mmole) in absolute ethanol $\left(\mathrm{L}_{\mathrm{I}} \mathrm{H}\right)$ or ethanol and dimethylsulfoxide $(1: 1 \mathrm{v} / \mathrm{v})\left(\mathrm{L}_{\mathrm{II}} \mathrm{H}\right)(5 \mathrm{~mL})$ was added an alcoholic solution $(5 \mathrm{~mL})$ of the metal salt (chlorides, nitrates, or acetates) ( $1 \mathrm{mmol}$ ), and the mixture was heated under reflux with continuous stirring for $3 \mathrm{~h}$. Precipitation of products took place after heating time of $30 \mathrm{~min}$ for $(\mathrm{Co}(\mathrm{II})), \mathrm{Ni}(\mathrm{II})$, and complexes of $\mathrm{L}_{\mathrm{I}} \mathrm{H}$ and $\mathrm{L}_{\mathrm{II}} \mathrm{H}\left(\mathrm{C}_{2}, \mathrm{C}_{3}, \mathrm{C}_{8}\right.$, and $\mathrm{C}_{9}$, resp. $), 1 \mathrm{~h}$ for $\left(\mathrm{Mn}(\mathrm{II}), \mathrm{Cu}(\mathrm{II})\right.$, and $\mathrm{Ir}(\mathrm{III})$ complex of $\mathrm{L}_{\mathrm{I}} \mathrm{H}$ and $\mathrm{Cd}(\mathrm{II})$ complex of $\mathrm{L}_{\mathrm{II}} \mathrm{H}\left(\mathrm{C}_{1}, \mathrm{C}_{4}, \mathrm{C}_{5}\right.$, and $\mathrm{C}_{12}$, resp.), $1.5 \mathrm{~h}$ for $\mathrm{Pt}(\mathrm{IV})$ complex of $\mathrm{L}_{\mathrm{I}} \mathrm{H}\left(\mathrm{C}_{7}\right), 2 \mathrm{~h}$ for $\mathrm{Pd}(\mathrm{II})$ complex of $\mathrm{L}_{\mathrm{I}} \mathrm{H}$ and $\mathrm{Pt}(\mathrm{IV})$ complex of $\mathrm{L}_{\mathrm{II}} \mathrm{H}\left(\mathrm{C}_{6}\right.$ and $\mathrm{C}_{11}$, resp.) and $3 \mathrm{~h}$ for $\mathrm{Pd}(\mathrm{II})$ complex of $\mathrm{L}_{\mathrm{II}} \mathrm{H}\left(\mathrm{C}_{10}\right)$. The products were filtered and purified from reactants by washing many times with ethanol and ether $\left(\mathrm{C}_{1}-\mathrm{C}_{7}\right)$ or with DMSO, ethanol and ether $\left(\mathrm{C}_{8}-\right.$ $\mathrm{C}_{12}$ ), and vacuum dried. Purity of the products was detected by TLC, using silica gel as a stationary phase and a mixture of chloroform and acetone $(2: 2 \mathrm{~V} / \mathrm{V})$ or various ratios of methyl acetate: acetone solvent mixture as eluents.

\section{Biological Activity Study}

5.1. Antibacterial Action. Antibacterial activities of the prepared compounds were tested against three types of pathogenic bacteria, namely, Escherichia coli, Staphylococcus areus, and Proteus mirabilis using the antibiotic Ceftriaxone as a control. Bacterial cultures were prepared by streaking (0.1) $\mathrm{mL}$ of $10^{6} \mathrm{CFU} / \mathrm{mL}$ broth of indicator strain on the whole surface of nutrient agar plate. In each plate four wells (pores) were created on the nutrient agar layer using sterile cork porer. In each hole was injected $50 \mu \mathrm{L}$ of $10^{-3} \mathrm{M}$ of the studied compounds in DMSO by micropipette. The resulting cultures were incubated at $37^{\circ} \mathrm{C}$ for $24 \mathrm{~h}$. The inhibition zones caused by each compound were measured, and the results were interpreted according to diameter measurements.

5.2. Cytotoxic Activity. A preliminary study of cytotoxic activity of some of the prepared compounds was performed against human epidermoid larynx carcinoma cell lines (Hep-2) of 52-year-old patient. Hep-2 monolayer cell lines were prepared by subculturing cell line into (RPMI-1640) medium supplemented with $10 \%$ heat deactivated fetal bovine serum. The resulting media were incubated at $37^{\circ} \mathrm{C}$ for $48 \mathrm{~h}$ until confluent layer was achieved. Four concentrations of investigated compounds were prepared: $62.5,125$, 250 , and $500 \mu \mathrm{g} / \mathrm{mL}$ using dimethyl sulfoxide (DMSO) as a diluent. Hep-2 cell line was plated into 96-well microtiter plates. Then $0.2 \mathrm{~mL}$ of each tested compound was added to each well in triplicates, and incubation was carried out for $48 \mathrm{~h}$. Cultures were stained with $50 \mu \mathrm{L} /$ well Neutral Red (NR) solution. The stained cultures were left in the incubator for further $2 \mathrm{~h}$, washed with phosphate buffered saline solution followed by $(0.1 \mathrm{~mL})$ ethanol phosphate buffered solution $\left(\mathrm{NaH}_{2} \mathrm{PO}_{4}\right.$ : ethanol $(1: 1)$, vehicle ethanol). The cytotoxic effects of the applied compounds were measured in terms of optical density of viable cells at $\lambda=492 \mathrm{~nm}$ using a Micro ELISA reader.

\section{Results and Discussions}

6.1. Synthesis. The synthesis of the two new ligands has been achieved by following two different pathways $\mathrm{A}$ and $\mathrm{B}$ as is illustrated by Scheme 2. Pathway A involves the synthesis of Schiff base precursor of isatin $(\mathrm{SBH})$ followed by condensation with the secondary amine, morpholine or diphenylamine, in presence of formaldehyde to form $\mathrm{L}_{\mathrm{I}} \mathrm{H}$ and $\mathrm{L}_{I I} \mathrm{H}$, respectively. Pathway $\mathrm{B}$ involves the formation 


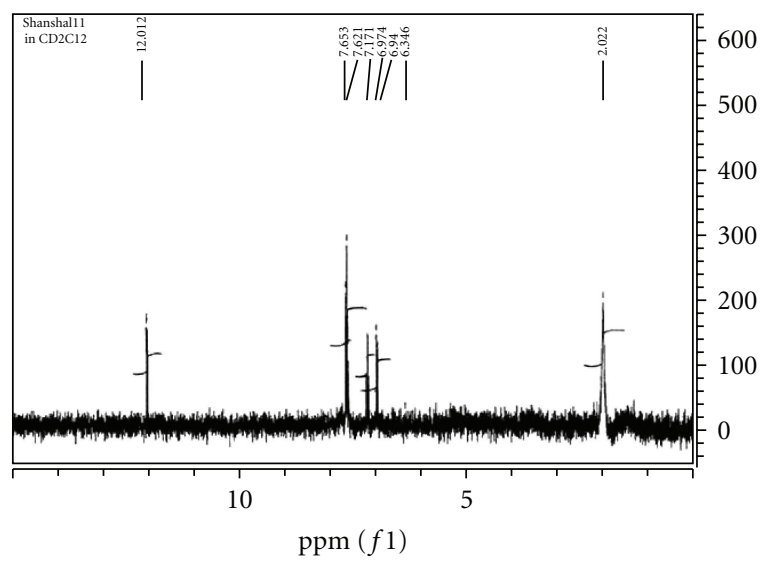

Figure 1: ${ }^{1} \mathrm{HNMR}$ Spectrum of $\mathrm{SBH}$ in $\mathrm{CD}_{2} \mathrm{Cl}_{2}$.

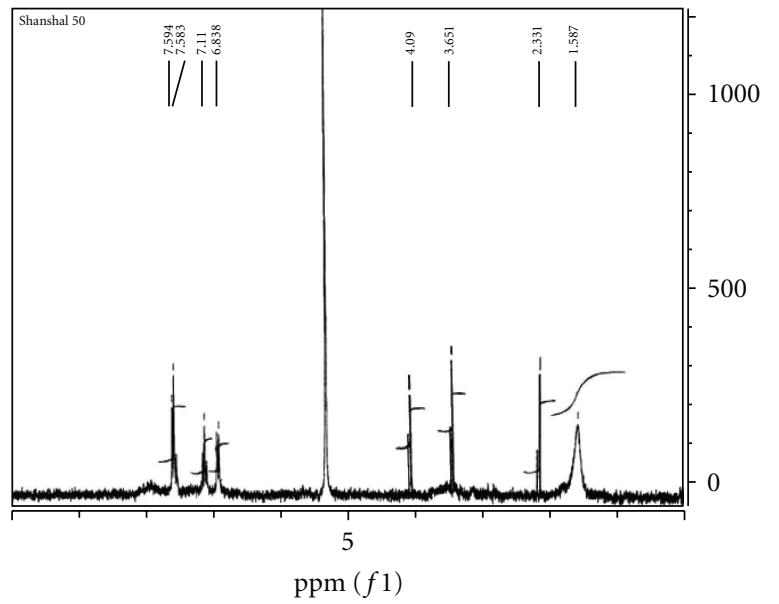

Figure 2: ${ }^{1} \mathrm{HNMR}$ Spectrum of $\mathrm{L}_{\mathrm{I}} \mathrm{H}$ in DMSO.

of Mannich base precusor of isatin $\left(\mathrm{M}_{\mathrm{I}}\right.$ and $\left.\mathrm{M}_{\mathrm{II}}\right)$ followed by condensation reaction with dithiooxamide. The second method showed lower yield and longer reaction time.

The ${ }^{1} \mathrm{H}$ n.m.r spectrum of the Schiff base precursor SBH in $\mathrm{CD}_{2} \mathrm{Cl}_{2}$ (Figure 1) is characterized by the appearance of chemical shift related to the $\mathrm{NH}_{2}$ protons of dto moiety at $\delta 2.022 \mathrm{ppm}[11,20,21]$ and the appearance of $\mathrm{NH}$ proton of isatin ring at $\delta 12.012 \mathrm{ppm}[5-7,22-25]$ which is quite agreeable with the suggested structure of $\mathrm{SBH}$. The ${ }^{1} \mathrm{H}$ n.m.r spectrum of $\mathrm{L}_{\mathrm{II}} \mathrm{H}$ in $\mathrm{CD}_{2} \mathrm{Cl}_{2}$ exhibited chemical shifts of $\mathrm{NH}_{2}$ protons at $2.17 \mathrm{ppm}$ while that of $\mathrm{L}_{\mathrm{I}} \mathrm{H}$ in DMSO (Figure 2) gave chemical shifts at $\delta 1.567 \mathrm{ppm}$. This was attributed to tautomerism of $\mathrm{L}_{\mathrm{I}} \mathrm{H}$ in DMSO to iminosulfhydryl structure in equilibrium with dithioamide structure, as a result of solvent polarity $[26,27]$. Such behavior was confirmed by the appearance of the signal assigned to imino $\mathrm{NH}$ group at lower field. The spectrum of $\mathrm{L}_{\mathrm{II}} \mathrm{H}$ (Figure 3) exhibited chemical shifts of aromatic protons of isatin ring and diphenylamine at $\delta 6.89-7.11$ and at $\delta 7.68-7.59$, respectively, while those of methylene group appeared at high fields [22-24].

The mass spectra of the two Mannich and Schiff base ligands as well as SBH are shown in Figures 4, 5, and 6 , respectively. The EI mode of mass spectrum displayed

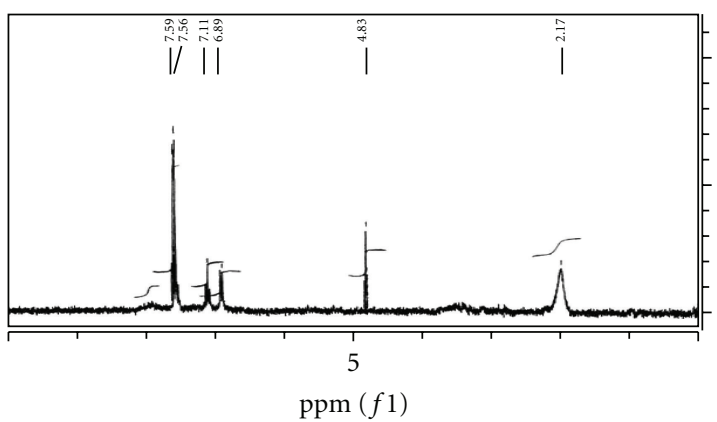

Figure 3: ${ }^{1} \mathrm{HNMR}$ of $\mathrm{L}_{\mathrm{II}} \mathrm{H}$ spectrum in $\mathrm{CD}_{2} \mathrm{Cl}_{2}$.

by SBH (Figure 6) gave a peak at $\mathrm{m} / \mathrm{z}=250$ which was assigned to $[\mathrm{M}+1]$, while the two Mannich base ligands displayed peaks corresponding to $\left[\mathrm{M}^{+}\right]$molecular ions. Smaller fragments were also observed and were characteristic of isatin behavior of other compounds [1,22, 26, 28-34]. The FAB and EI modes of $\mathrm{L}_{\mathrm{I}} \mathrm{H}$ (Figures 4(a) and 4(b)) showed different intensities of common fragments ions.

The IR spectra of the three organic compounds exhibited the disappearance of stretching modes assigned to C-3 carbonyl of isatin ring and appearance of stretching modes of azomethine group of Schiff base products at $1614 \mathrm{~cm}^{-1}$ [35]. Stretching vibrations of C-2 carbonyl group of isatin ring for $\mathrm{SBH}$ and the two Mannich Schiff base ligands were observed at $1733-1730 \mathrm{~cm}^{-1}$ [35]. The presence of bands assigned to $\mathrm{NH}_{2}$ asymmetric symmetric stretching vibrations indicates that the formation of Schiff bases was through one $\mathrm{NH}_{2}$ group only. Both ligands exhibited the absence of stretching vibrations assigned to $\mathrm{NH}$ of isatin ring, and instead vibrational modes of $\mathrm{N}-\mathrm{CH}_{2}$ groups were observed at $2813-2304 \mathrm{~cm}^{-1}$ [35]. Bands observed at 1149, 1328 in the spectrum of $\mathrm{L}_{\mathrm{I}} \mathrm{H}$ were attributed to $\mathrm{C}-\mathrm{O}-\mathrm{C}$ and $\mathrm{C}-\mathrm{N}-\mathrm{C}$ vibration of morpholine ring, respectively [35-38].

6.2. Physical Properties and Analytical Data of Metal Complexes. The color, melting points, yields, and elemental analyses of the prepared metal complexes of isatin Schiff Mannich base ligands are described in Table 1. Most results were in agreement with the suggested formula. Some deviations in elemental analyses may be attributed to incomplete combustion of the complexes. The low yield resulted from extensive purification of products from the starting materials as was indicated from TLC results.

6.3. Infrared Spectra. The important stretching vibrations of $\mathrm{L}_{\mathrm{I}} \mathrm{H}$ and $\mathrm{L}_{\mathrm{II}} \mathrm{H}$ metal complexes are described in Table 2. The $\mathrm{Mn}(\mathrm{II}), \mathrm{Co}(\mathrm{II})$ and $\mathrm{Ni}(\mathrm{II})$ complexes of $\mathrm{L}_{\mathrm{I}} \mathrm{H}\left(\mathrm{C}_{1}-\mathrm{C}_{3}\right.$, resp.) and $\mathrm{Co}(\mathrm{II})$ complex of $\mathrm{L}_{\mathrm{II}} \mathrm{H}\left(\mathrm{C}_{8}\right)$ exhibited shifts of the thioamide groups to lower frequencies indicating the involvement of thiocarbonyl sulfur atoms in coordination with these metal ions $[39,40]$. The spectra of $C_{1}$ and $\mathrm{C}_{2}$ demonstrated further shift of $\mathrm{NH}_{2}$ group vibrational modes to lower frequencies as a result of bonding. On the other hand the spectra of $\mathrm{Cu}(\mathrm{II}), \operatorname{Ir}(\mathrm{III})$, and $\mathrm{Pt}(\mathrm{IV})$ complexes of $\mathrm{L}_{\mathrm{I}} \mathrm{H}\left(\mathrm{C}_{4}, \mathrm{C}_{6}, \mathrm{C}_{7}\right.$, resp.) and $\mathrm{Pd}(\mathrm{II}), \mathrm{Pt}(\mathrm{IV})$, 


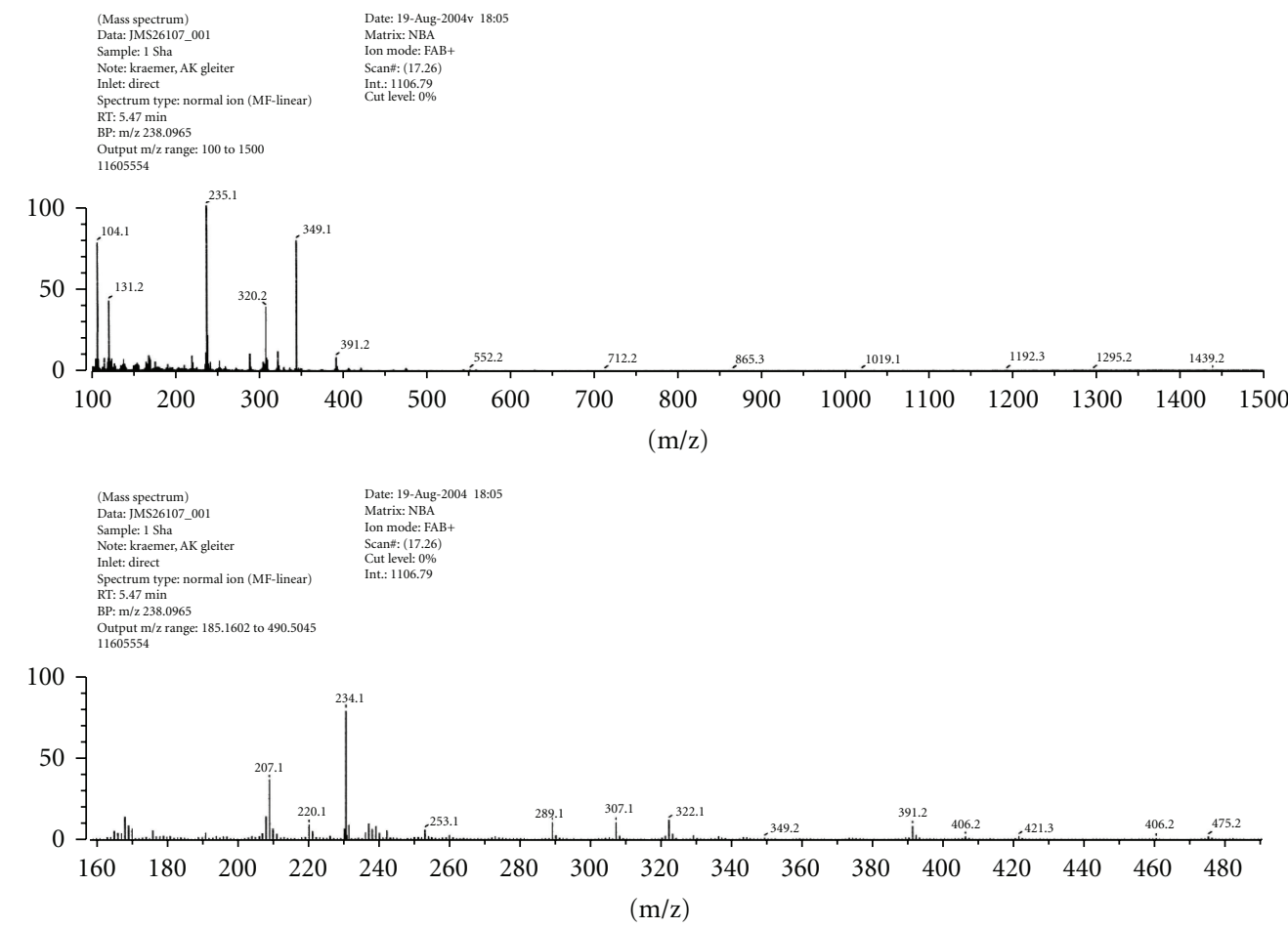

(a)

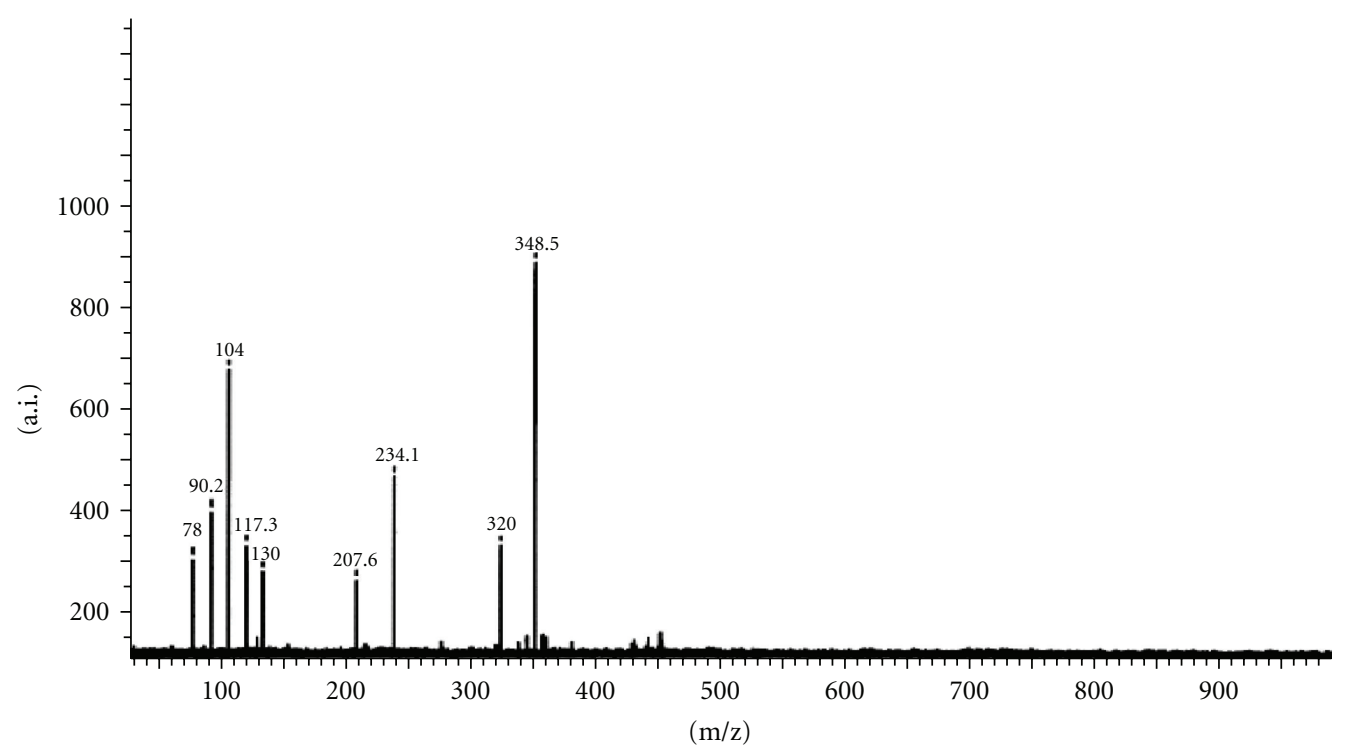

(b)

FIgUre 4: Mass spectrum of $\mathrm{L}_{\mathrm{I}} \mathrm{H}$ by (a) FAB and (b) EI modes.

and $\mathrm{Cd}(\mathrm{II})$ complexes of $\mathrm{L}_{\mathrm{II}} \mathrm{H}\left(\mathrm{C}_{10}-\mathrm{C}_{12}\right.$, resp. $)$ displayed the disappearance of the stretching mode of thioamide $\mathrm{NH}_{2}$ group and the shift of C-S band to lower frequencies. This refers to the bonding of metal ion to the deprotonated group of the ligand in the form of $-{ }_{\mathrm{C}}^{\|}-\mathrm{SH}$ as in $\mathrm{C}_{4}, \mathrm{C}_{6}$, and $\mathrm{C}_{9}$ or in the form of $-{ }_{\mathrm{C}}-\stackrel{\mathrm{NH}}{\mathrm{S}}$ anion as in the case of $\mathrm{C}_{5}, \mathrm{C}_{7}$, and $\mathrm{C}_{10}-\mathrm{C}_{12}$. The appearance of stretching modes assigned to $\mathrm{NH}$ and $\mathrm{C}=\mathrm{N}$ of $-\mathrm{C}=\mathrm{NH}$ groups was observed at $3371-$ 3100 and $1640-1620 \mathrm{~cm}^{-1}$, respectively $[15,35,39,41]$. The stretching vibrations of azomethine group of the Schiff base ligands were shifted to lower frequencies in all spectra except those of $\mathrm{C}_{6}, \mathrm{C}_{10}$, and $\mathrm{C}_{12}$, whereas stretching vibrations of carbonyl group were shifted to lower frequencies in all spectra except $\mathrm{C}_{1}, \mathrm{C}_{4}, \mathrm{C}_{6}$, and $\mathrm{C}_{10}$ indicating additional 


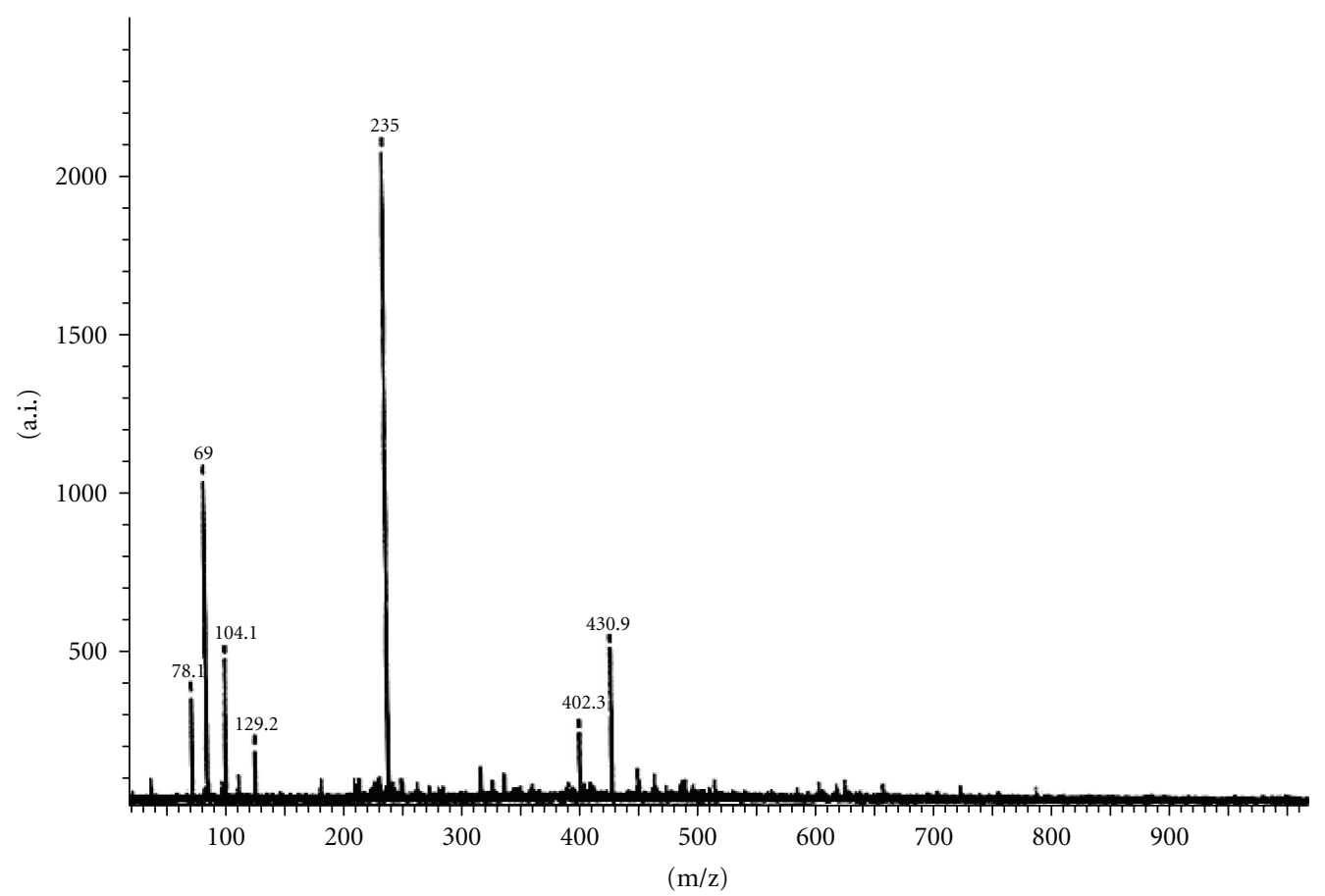

Figure 5: Mass spectrum of $\mathrm{L}_{\mathrm{II}} \mathrm{H}$.

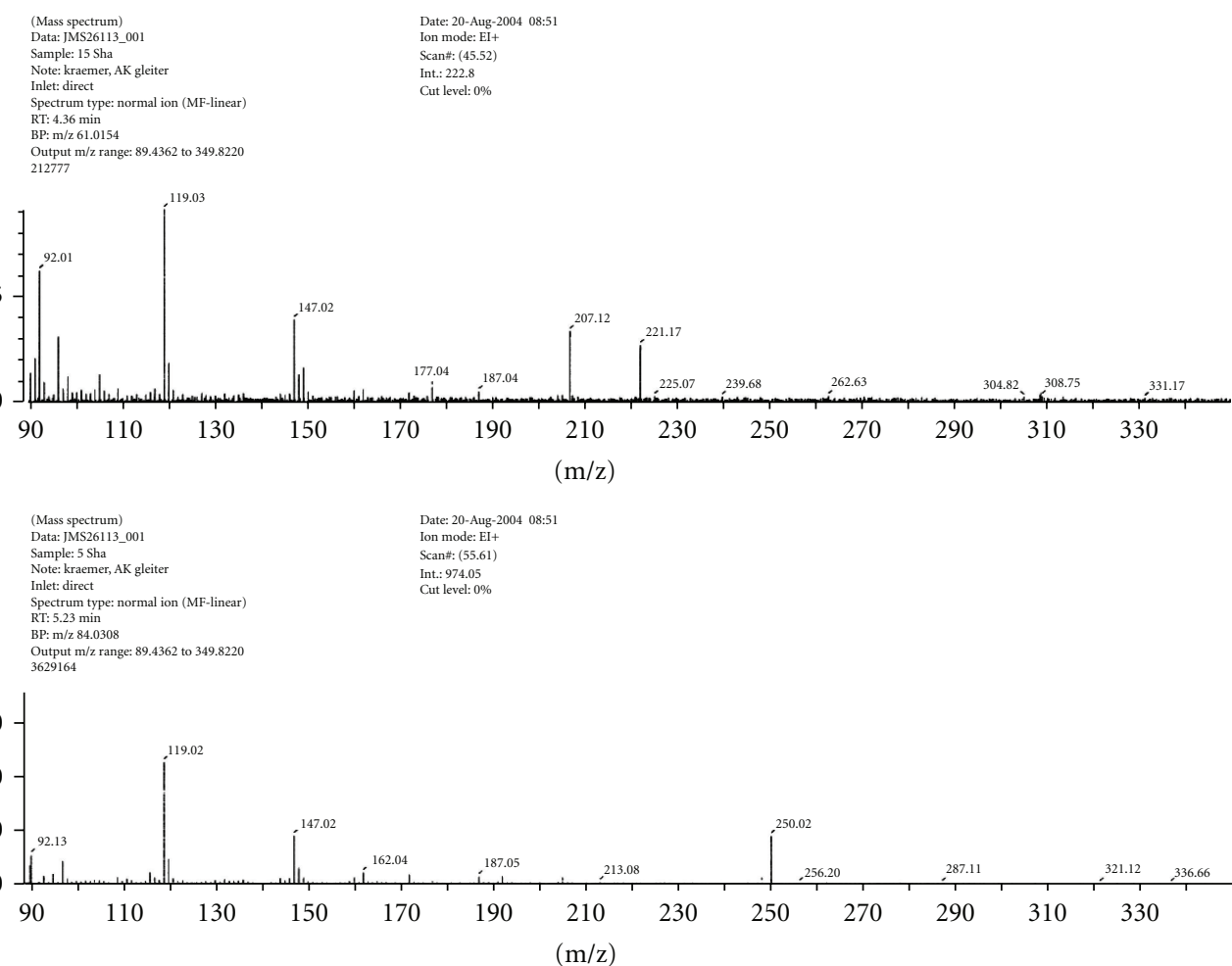

Figure 6: Mass spectrum of SBH. 
TABLE 1: Physical properties and analytical data of the prepared Schiff and Mannich base complexes.

\begin{tabular}{|c|c|c|c|c|c|c|c|}
\hline \multirow{2}{*}{$\begin{array}{l}\text { Molecular formula } \\
\text { (Color) }\end{array}$} & \multirow{2}{*}{$\begin{array}{l}\text { m.p. (decomposition) } \\
\text { temp. }{ }^{\circ} \mathrm{C}\end{array}$} & \multirow{2}{*}{ Yield \% } & \multicolumn{5}{|c|}{ \% element analysis found (calculated) } \\
\hline & & & $\mathrm{C}$ & $\mathrm{H}$ & $\mathrm{N}$ & M & $\mathrm{Cl}$ \\
\hline $\begin{array}{l}{\left[\mathrm{Mn}\left(\mathrm{L}_{\mathrm{I}} \mathrm{H}\right)\left(\mathrm{H}_{2} \mathrm{O}\right) \mathrm{Cl}_{2}\right] 2.5 \mathrm{H}_{2} \mathrm{O}} \\
(\text { Brown })\left(\mathrm{C}_{1}\right)\end{array}$ & 215 & 42.24 & $\begin{array}{c}33.91 \\
(33.46)\end{array}$ & $\begin{array}{c}4.22 \\
(4.27)\end{array}$ & $\begin{array}{c}11.18 \\
(10.40)\end{array}$ & $\begin{array}{c}10.66 \\
(10.20)\end{array}$ & $\begin{array}{c}13.11 \\
(13.19)\end{array}$ \\
\hline $\begin{array}{l}{\left[\mathrm{Co}\left(\mathrm{L}_{\mathrm{I}} \mathrm{H}\right)\left(\mathrm{NO}_{3}\right)_{2}\right] \mathrm{H}_{2} \mathrm{O} \text { (Brown) }} \\
\left(\mathrm{C}_{2}\right)\end{array}$ & 174 & 61.11 & $\begin{array}{c}33.11 \\
(32.77)\end{array}$ & $\begin{array}{c}3.02 \\
(3.27)\end{array}$ & $\begin{array}{c}16.09 \\
(15.29)\end{array}$ & $\begin{array}{c}10.50 \\
(10.73)\end{array}$ & - \\
\hline $\begin{array}{l}{\left[\mathrm{Ni}\left(\mathrm{L}_{\mathrm{I}} \mathrm{H}\right)_{2}\right] 2 \mathrm{NO}_{3} \cdot \mathrm{H}_{2} \mathrm{O}(\text { Bright }} \\
\text { blue) }\left(\mathrm{C}_{3}\right)\end{array}$ & $>300$ & 50.8 & $\begin{array}{c}40.90 \\
(40.13)\end{array}$ & $\begin{array}{c}3.62 \\
(3.78)\end{array}$ & $\begin{array}{c}16.06 \\
(15.60)\end{array}$ & $\begin{array}{c}5.78 \\
(6.54)\end{array}$ & - \\
\hline $\begin{array}{l}{\left[\mathrm{Cu}_{2}\left(\mathrm{~L}_{\mathrm{I}} \mathrm{H}\right)_{2} \mathrm{Cl}\left(\mathrm{H}_{2} \mathrm{O}\right)_{4}\right] \mathrm{Cl}_{3} \text { (Reddish }} \\
\text { brown) }\left(\mathrm{C}_{4}\right)\end{array}$ & $>300$ & 77.11 & $\begin{array}{c}40.25 \\
(39.85)\end{array}$ & $\begin{array}{c}4.32 \\
(4.43)\end{array}$ & $\begin{array}{c}6.81 \\
(6.20)\end{array}$ & $\begin{array}{l}13.73 \\
(14.07)\end{array}$ & $\begin{array}{l}7.26 \\
(7.86)\end{array}$ \\
\hline $\begin{array}{l}{\left[\mathrm{PdL}_{\mathrm{I}}\right] \mathrm{Cl} \cdot 1.5 \mathrm{H}_{2} \mathrm{O}(\text { Dark brown })} \\
\left(\mathrm{C}_{5}\right)\end{array}$ & 250 & 59.21 & $\begin{array}{c}34.45 \\
(34.82)\end{array}$ & $\begin{array}{c}3.01 \\
(3.48)\end{array}$ & $\begin{array}{c}11.32 \\
(10.80)\end{array}$ & - & $\begin{array}{c}7.01 \\
(6.86)\end{array}$ \\
\hline $\begin{array}{l}{\left[\mathrm{Ir}\left(\mathrm{L}_{\mathrm{I}} \mathrm{H}\right)_{2} \mathrm{Cl}_{2}\right] \mathrm{Cl} \cdot \mathrm{H}_{2} \mathrm{O} \text { (Pale yellow) }} \\
\left(\mathrm{C}_{6}\right)\end{array}$ & 230 & 32.31 & $\begin{array}{c}34.73 \\
(35.51)\end{array}$ & $\begin{array}{c}3.32 \\
(3.55)\end{array}$ & $\begin{array}{c}11.82 \\
(11.05)\end{array}$ & $\begin{array}{c}19.56 \\
(19.12)\end{array}$ & $\begin{array}{c}9.98 \\
(10.50)\end{array}$ \\
\hline $\begin{array}{l}{\left[\mathrm{Pt}\left(\mathrm{L}_{\mathrm{I}}\right) \mathrm{Cl}_{3}\right] 0.5 \mathrm{H}_{2} \mathrm{O} \text { (Yellow brown) }} \\
\left(\mathrm{C}_{7}\right)\end{array}$ & $>300$ & 34.01 & $\begin{array}{c}27.78 \\
(27.31)\end{array}$ & $\begin{array}{c}2.49 \\
(2.58)\end{array}$ & $\begin{array}{c}8.82 \\
(8.49)\end{array}$ & $\begin{array}{c}28.89 \\
(29.60)\end{array}$ & $\begin{array}{c}16.82 \\
(16.16)\end{array}$ \\
\hline $\begin{array}{l}{\left[\mathrm{Co}_{2}\left(\mathrm{~L}_{\mathrm{II}} \mathrm{H}\right)_{2}\left(\mathrm{NO}_{3}\right)_{4}\right] \cdot 2 \mathrm{H}_{2} \mathrm{O}(\text { Dark }} \\
\text { green })\left(\mathrm{C}_{8}\right)\end{array}$ & 235 & 42.15 & $\begin{array}{c}44.62 \\
(43.74)\end{array}$ & $\begin{array}{l}3.71 \\
(3.17)\end{array}$ & $\begin{array}{c}13.64 \\
(13.31)\end{array}$ & $\begin{array}{c}8.89 \\
(9.34)\end{array}$ & - \\
\hline$\left[\mathrm{Ni}\left(\mathrm{L}_{\mathrm{II}} \mathrm{H}\right)(\mathrm{OAc})_{2}\right]($ Blue $)\left(\mathrm{C}_{9}\right)$ & 243 & 50.32 & $\begin{array}{c}52.84 \\
(53.40)\end{array}$ & $\begin{array}{c}3.54 \\
(3.95)\end{array}$ & $\begin{array}{c}9.43 \\
(9.23)\end{array}$ & $\begin{array}{l}9.72 \\
(9.23)\end{array}$ & - \\
\hline $\begin{array}{l}{\left[\mathrm{PdL}_{\mathrm{II}} \mathrm{Cl}\right]_{2} 1.5 \mathrm{H}_{2} \mathrm{O} \text { (Dark brown) }} \\
\left(\mathrm{C}_{10}\right)\end{array}$ & $>280$ & 23.30 & $\begin{array}{c}46.51 \\
(46.86)\end{array}$ & $\begin{array}{c}3.81 \\
(3.23)\end{array}$ & $\begin{array}{l}10.11 \\
(9.51)\end{array}$ & - & $\begin{array}{c}6.40 \\
(6.03)\end{array}$ \\
\hline $\begin{array}{l}{\left[\mathrm{Pt}\left(\mathrm{L}_{\mathrm{II}}\right) \mathrm{Cl}_{2} \cdot \mathrm{H}_{2} \mathrm{O}\right] \mathrm{Cl} \cdot \mathrm{H}_{2} \mathrm{O} \text { (Brown) }} \\
\left(\mathrm{C}_{11}\right)\end{array}$ & 250 & 33.23 & $\begin{array}{c}36.21 \\
(35.95)\end{array}$ & $\begin{array}{c}2.13 \\
(2.87)\end{array}$ & $\begin{array}{c}8.23 \\
(7.29)\end{array}$ & $\begin{array}{c}24.77 \\
(25.40)\end{array}$ & $\begin{array}{c}13.09 \\
(13.87)\end{array}$ \\
\hline $\begin{array}{l}{\left[\mathrm{CdL}_{\mathrm{II}}(\mathrm{OAc})\left(\mathrm{H}_{2} \mathrm{O}\right)_{2}\right]_{2} \text { (Yellow) }} \\
\left(\mathrm{C}_{12}\right)\end{array}$ & 260 & 20.57 & $\begin{array}{c}46.65 \\
(47.06) \\
\end{array}$ & $\begin{array}{c}3.62 \\
(3.29)\end{array}$ & $\begin{array}{c}9.50 \\
(8.77)\end{array}$ & $\begin{array}{c}16.95 \\
(17.63)\end{array}$ & - \\
\hline
\end{tabular}

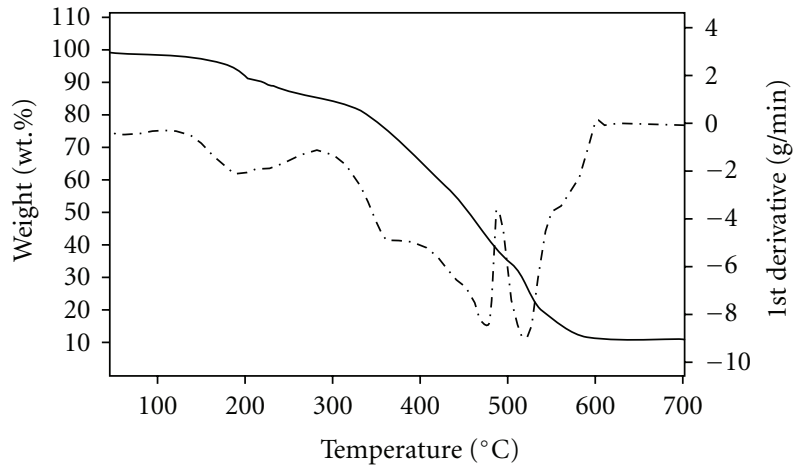

Figure 7: Thermographs of the $\mathrm{Co}(\mathrm{II})$ complex of $\mathrm{L}_{\mathrm{I}} \mathrm{H}\left(\mathrm{C}_{2}\right)$.

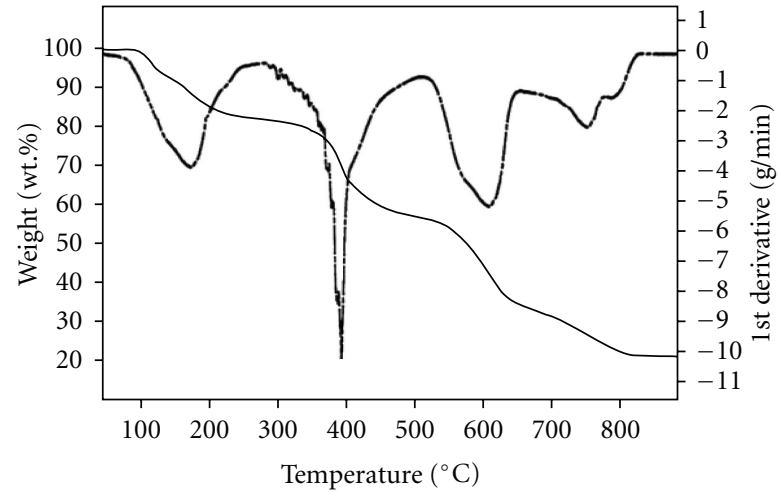

Figure 8: Thermographs of the $\operatorname{Ir}(\mathrm{III})$ complex of $\mathrm{L}_{\mathrm{I}} \mathrm{H}\left(\mathrm{C}_{6}\right)$. coordination of metal ions to $\mathrm{C}=\mathrm{N}$ and $\mathrm{C}=\mathrm{O}$ groups [36-38]. Bands related to coordinated water vibrations were observed in the spectra of $C_{1}, C_{4}$, and $C_{12}$ at $(3490,756,640),(3480$, $800,730)$, and $(3500,864,710) \mathrm{cm}^{-1}$, respectively, and to lattice water vibrations at frequency range $3519-3464 \mathrm{~cm}^{-1}$ in the other complexes. The bands related to nitrate ions were observed in the spectra of $\mathrm{C}_{2}$ and $\mathrm{C}_{3}$ at $(1522,1478)$, $(1765,1641) \mathrm{cm}^{-1}$ and were assigned to monodentate and free ion behaviors, respectively, whereas that of $\mathrm{C}_{8}$ appeared at $1750-1660$ and $1406-1380 \mathrm{~cm}^{-1}$ showing monodentate and bidentate behaviors, respectively [42]. Bands attributed to acetate group vibrations were observed in the spectra of $\mathrm{C}_{9}$ and $C_{12}$ at $(1645,1340)$ and $(1590,1465) \mathrm{cm}^{-1}$, respectively, indicating monodentate and bidentate bridging behaviors, respectively [42]. Additional bands were observed at lower frequencies $\left(600-250 \mathrm{~cm}^{-1}\right)$ and were attributed to $\mathrm{M}-\mathrm{N}$, $\mathrm{M}-\mathrm{O}, \mathrm{M}-\mathrm{S}$, and $\mathrm{M}-\mathrm{X}\left(\mathrm{X}=\right.$ acetate, $\left.\mathrm{NO}_{3}^{-}, \mathrm{Cl}^{-}\right)$stretching modes [42]. 
TABle 2: Important I.R. vibrations $\left(\mathrm{cm}^{-1}\right)$ for the two Mannich and Schiff base ligands and their metal complexes.

\begin{tabular}{|c|c|c|c|c|c|c|c|c|c|c|c|c|}
\hline \multirow{2}{*}{ Symbol } & \multirow[b]{2}{*}{$v_{\mathrm{NH} 2}$} & \multirow{2}{*}{${ }_{\mathrm{C}}^{v}=\mathrm{N}^{\mathrm{H}}$} & \multirow[b]{2}{*}{$v_{\mathrm{C}=\mathrm{O}}$} & \multirow[b]{2}{*}{$\nu_{\mathrm{C}=\mathrm{N}}$} & \multicolumn{4}{|c|}{ Thioamide group } & \multirow[b]{2}{*}{$\nu_{\mathrm{M}-\mathrm{N}}$} & \multirow[b]{2}{*}{$v_{\mathrm{M}-\mathrm{O}}$} & \multirow[b]{2}{*}{$\nu_{\mathrm{M}-\mathrm{S}}$} & \multirow[b]{2}{*}{$v_{\mathrm{M}-\mathrm{Cl}}$} \\
\hline & & & & & $\begin{array}{c}\text { Band (I) } \\
\delta_{\mathrm{N}-\mathrm{H}}+ \\
v_{\mathrm{C}-\mathrm{S}}\end{array}$ & $\begin{array}{c}\text { Band (II) } \\
v_{\mathrm{C}-\mathrm{N}} \\
+v_{\mathrm{C}-\mathrm{S}}\end{array}$ & $\begin{array}{c}\text { Band (III) } \\
v_{\mathrm{C}-\mathrm{S}}\end{array}$ & $\begin{array}{c}\text { Band (IV) } \\
v_{\mathrm{C}=\mathrm{S}}\end{array}$ & & & & \\
\hline $\mathrm{L}_{\mathrm{I}} \mathrm{H}$ & $\begin{array}{l}3138 \\
3203\end{array}$ & - & $\begin{array}{l}1730- \\
1735\end{array}$ & 1614 & 1540 & 1429 & 1195 & 835 & - & - & - & - \\
\hline $\begin{array}{l}\mathrm{C}_{1} \\
\mathrm{Mn}(\mathrm{II})\end{array}$ & $\begin{array}{l}3124 \\
3371\end{array}$ & - & 1732 & 1600 & 1510 & 1434 & 1190 & 820 & 248 & 283 & 325 & $246^{\mathrm{a}}$ \\
\hline $\begin{array}{l}\mathrm{C}_{2} \\
\mathrm{Co}(\mathrm{II})\end{array}$ & $\begin{array}{l}3072 \\
3263\end{array}$ & - & 1724 & 1602 & 1530 & 1433 & 1163 & 777 & 230 & 460 & 330 & - \\
\hline $\begin{array}{l}\mathrm{C}_{3} \\
\mathrm{Ni}(\mathrm{II})\end{array}$ & $\begin{array}{l}3133 \\
3213\end{array}$ & - & 1720 & 1595 & 1535 & 1427 & 1150 & 827 & 293 & 464 & 330 & - \\
\hline $\begin{array}{l}\mathrm{C}_{4} \\
\mathrm{Cu}(\mathrm{II})\end{array}$ & - & 3315 & 1735 & $\begin{array}{l}1600 \\
1650\end{array}$ & 1535 & 1434 & 1190 & 792 & $\begin{array}{l}250 \\
302\end{array}$ & 457 & 350 & $222^{\mathrm{b}}$ \\
\hline $\begin{array}{l}\mathrm{C}_{5} \\
\mathrm{Pd}(\mathrm{II})\end{array}$ & - & 3392 & 1708 & 1604 & 1537 & 1430 & 1190 & 815 & 240 & 459 & 323 & - \\
\hline $\begin{array}{l}\mathrm{C}_{6} \\
\operatorname{Ir}(\mathrm{III})\end{array}$ & - & 3342 & 1735 & $\begin{array}{l}1614 \\
1650\end{array}$ & 1539 & 1400 & 1151 & 810 & 350 & - & 330 & $253^{\mathrm{a}}$ \\
\hline $\begin{array}{l}\mathrm{C}_{7} \\
\mathrm{Pt}(\mathrm{IV})\end{array}$ & - & 3168 & 1700 & 1650 & 1517 & 1446 & 1114 & 833 & 254 & 462 & 329 & $297^{\mathrm{a}}$ \\
\hline $\mathrm{L}_{\mathrm{II}} \mathrm{H}$ & $\begin{array}{l}3043 \\
3193\end{array}$ & - & 1730 & 1614 & 1540 & 1434 & 1195 & 833 & - & - & - & - \\
\hline $\begin{array}{l}\mathrm{C}_{8} \\
\mathrm{Co}(\mathrm{II})\end{array}$ & $\begin{array}{l}3151 \\
3321\end{array}$ & - & 1700 & 1602 & 1585 & 1440 & 1130 & 800 & 393 & 400 & 327 & - \\
\hline $\begin{array}{l}\mathrm{C}_{9} \\
\mathrm{Ni}(\mathrm{II})\end{array}$ & 3249 & 3249 & 1695 & 1600 & 1583 & 1484 & 1150 & 809 & 246 & 478 & 320 & - \\
\hline $\begin{array}{l}\mathrm{C}_{10} \\
\mathrm{Pd}(\mathrm{II})\end{array}$ & - & $\begin{array}{l}3425 \\
3249\end{array}$ & 1735 & $\begin{array}{l}1619 \\
1647\end{array}$ & 1587 & 1450 & 1155 & 820 & 464 & - & 323 & $\begin{array}{l}240^{\mathrm{b}} \\
210\end{array}$ \\
\hline $\begin{array}{l}\mathrm{C}_{11} \\
\mathrm{Pt}(\mathrm{IV})\end{array}$ & - & 3230 & 1730 & $\begin{array}{l}1616 \\
1650\end{array}$ & 1530 & 1430 & 1150 & 802 & 468 & 450 & 325 & $291^{\mathrm{a}}$ \\
\hline $\begin{array}{l}\mathrm{C}_{12} \\
\mathrm{Cd}(\mathrm{II})\end{array}$ & - & 3300 & 1735 & $\begin{array}{l}1616 \\
1650\end{array}$ & 1488 & 1430 & 1161 & 800 & 288 & $\begin{array}{l}468 \\
450\end{array}$ & 325 & - \\
\hline
\end{tabular}




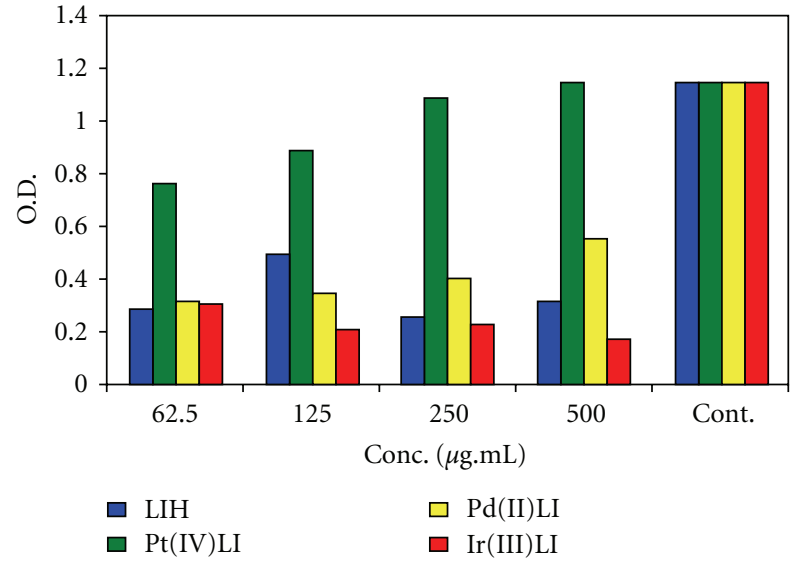

(a)

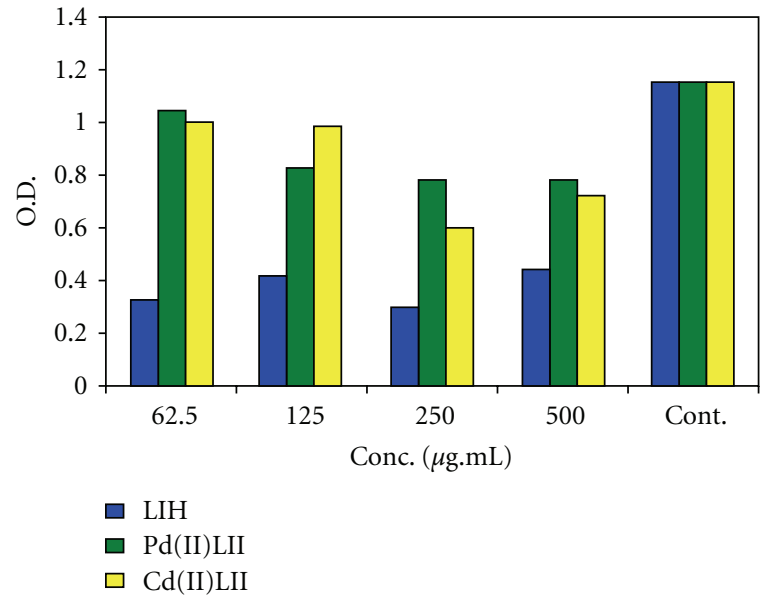

(b)

Figure 9: Cytotoxic effect of $\mathrm{L}_{\mathrm{I}} \mathrm{H}, \mathrm{L}_{\mathrm{II}} \mathrm{H}$, and some selected metal complexes on growth of cancer cell line Hep-2 at different concentrations with exposure time $48 \mathrm{~h}$.

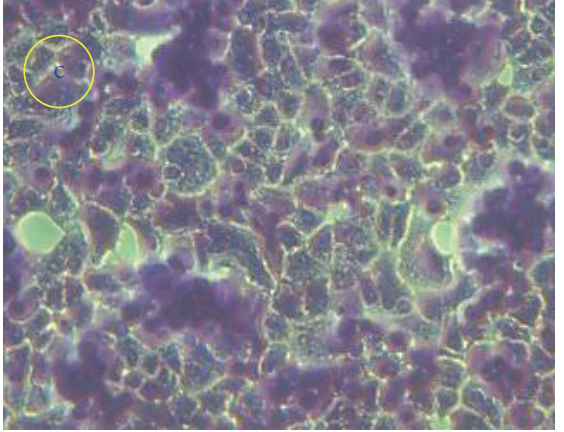

(a)

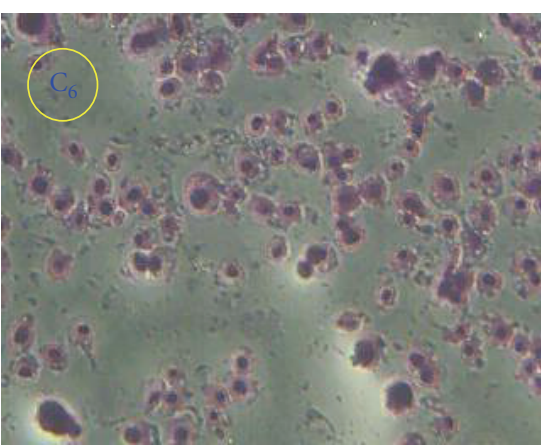

(b)

Figure 10: Tissue culture sections of Hep-2 cell line before (c) and after treatment with $\operatorname{IrL}_{\mathrm{I}}\left(\mathrm{C}_{6}\right)$.

6.4. Thermal Analysis. Steps of thermal decomposition of the $\mathrm{Co}(\mathrm{II})$ and $\operatorname{Ir}(\mathrm{III})$ complexes of $\mathrm{L}_{\mathrm{I}} \mathrm{H}\left(\mathrm{C}_{2}, \mathrm{C}_{6}\right)$ following TG and DTG curves under nitrogen atmosphere and heating range $50-800^{\circ} \mathrm{C}$ are described in Table 3 , and their thermographs are shown in Figures 7 and 8, respectively. At low temperatures, the initial weight losses were determined from TG curves referred to loss of water of crystallization [4345]. The final stage of thermal decomposition of $\mathrm{C}_{2}$ gave the metal oxide whereas the Ir complex $\left(\mathrm{C}_{6}\right)$ gave the free metal as a final residue [43-45].

6.5. Electronic Spectra and Suggested Structures. Table 4 describes the energies of bands observed in the spectra of metal complexes and their assignments together with magnetic moments and molar conductivity in $\operatorname{DMF}\left(10^{-3} \mathrm{M}\right)$. The spectral parameters $10 \mathrm{Dq}, \mathrm{Dq} / \bar{B}, \bar{B}$, and $\beta$ as well as energies of unobserved ligand field bands were obtained by applying observed band energies and band ratios on Tanabe-Saugano diagrams of the specified metal ion [46-48].
All metal complexes exhibited spectra related to octahedral arrangement of ligand atoms around the metal ions except those of palladium(II) as they gave square planar geometries. The high values of magnetic moments of $\mathrm{Co}(\mathrm{II}), \mathrm{Ni}(\mathrm{II})$, and $\mathrm{Cu}$ (II) complexes are attributed to spin-orbital coupling [49]. All complexes were of high-spin octahedral geometries except $\mathrm{Pt}(\mathrm{IV}), \operatorname{Ir}(\mathrm{III})$, and $\mathrm{Cd}(\mathrm{II})$ complexes which were diamagnetic and so were $\mathrm{Pd}(\mathrm{II})$ complexes.

The spectrum of the $\mathrm{Cd}(\mathrm{II})$ complex $\left(\mathrm{C}_{12}\right)$ exhibited charge transfer bands only, which is a common phenomenon for $\mathrm{d}^{10}$ metal complexes where $\mathrm{d}-\mathrm{d}$ transitions are excluded $[47,48]$. Conductivity measurement of metal complexes in DMF solution $\left(10^{-3} \mathrm{M}\right)$ showed nonelectrolytic nature of $\mathrm{Mn}(\mathrm{II}), \mathrm{Co}(\mathrm{II})$, and $\mathrm{Pt}(\mathrm{IV})$ complexes of $\mathrm{L}_{\mathrm{I}} \mathrm{H}\left(\mathrm{C}_{1}, \mathrm{C}_{2}\right.$, and $\mathrm{C}_{7}$, resp.) and $\mathrm{Co}(\mathrm{II}), \mathrm{Ni}(\mathrm{II}), \mathrm{Pd}(\mathrm{II})$, and $\mathrm{Cd}(\mathrm{II})$ complexes of $\mathrm{L}_{\mathrm{II}} \mathrm{H}\left(\mathrm{C}_{8}-\mathrm{C}_{10}\right.$ and $\mathrm{C}_{12}$, resp.) [50]. Electrolytic nature of $1: 1$ was exhibited by $\mathrm{Pd}(\mathrm{II}), \operatorname{Ir}(\mathrm{III})$ complexes of $\mathrm{L}_{\mathrm{I}} \mathrm{H}\left(\mathrm{C}_{5}\right.$ and $\mathrm{C}_{6}$ ) and $\mathrm{Pt}(\mathrm{IV})$ complex of $\mathrm{L}_{\mathrm{II}} \mathrm{H}\left(\mathrm{C}_{11}\right), 1: 2$ by $\mathrm{Ni}(\mathrm{II})$ complex of $\mathrm{L}_{\mathrm{I}} \mathrm{H}\left(\mathrm{C}_{3}\right)$ and $1: 3$ by $\mathrm{Cu}(\mathrm{II})$ complex of $\mathrm{L}_{\mathrm{I}} \mathrm{H}\left(\mathrm{C}_{4}\right)$ 
$\mathrm{C}_{1}:\left[\mathrm{Mn}\left(\mathrm{L}_{\mathrm{I}} \mathrm{H}\right) \mathrm{Cl}_{2}\left(\mathrm{H}_{2} \mathrm{O}\right)\right] \cdot 2.5 \mathrm{H}_{2} \mathrm{O}$

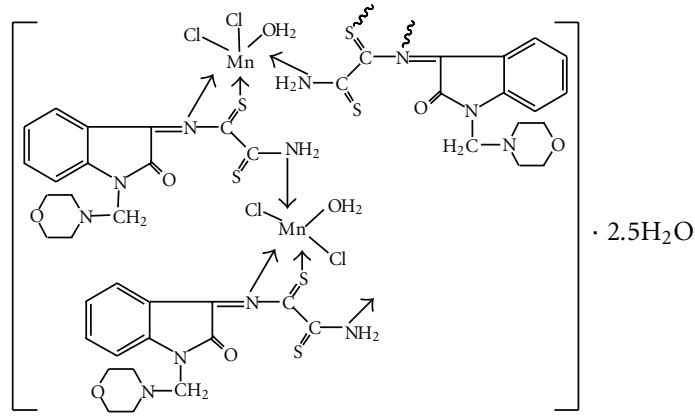

$\mathrm{C}_{2}:\left[\mathrm{Co}\left(\mathrm{L}_{\mathrm{I}} \mathrm{H}\right)\left(\mathrm{NO}_{3}\right)_{2}\right] \cdot \mathrm{H}_{2} \mathrm{O}$

$\mathrm{C}_{3}:\left[\mathrm{Ni}\left(\mathrm{L}_{\mathrm{I}} \mathrm{H}\right)_{2}\right] 2\left(\mathrm{NO}_{3}\right) \cdot \mathrm{H}_{2} \mathrm{O}$
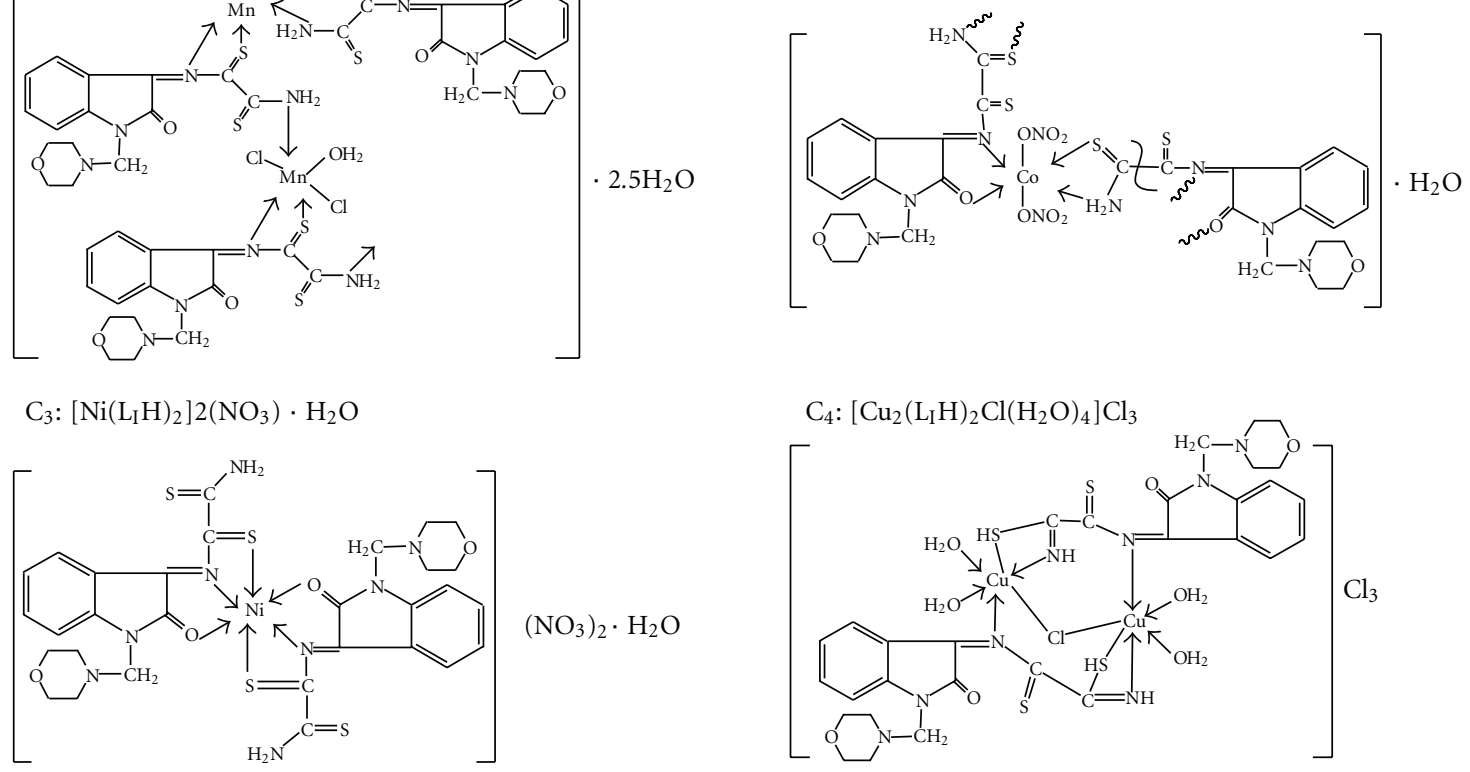

$\left(\mathrm{NO}_{3}\right)_{2} \cdot \mathrm{H}_{2} \mathrm{O}$

$\mathrm{C}_{4}:\left[\mathrm{Cu}_{2}\left(\mathrm{~L}_{\mathrm{I}} \mathrm{H}\right)_{2} \mathrm{Cl}\left(\mathrm{H}_{2} \mathrm{O}\right)_{4}\right] \mathrm{Cl}_{3}$

$\mathrm{C}_{5}:\left[\mathrm{PdL}_{\mathrm{I}}\right] \mathrm{Cl} \cdot 1.5 \mathrm{H}_{2} \mathrm{O}$

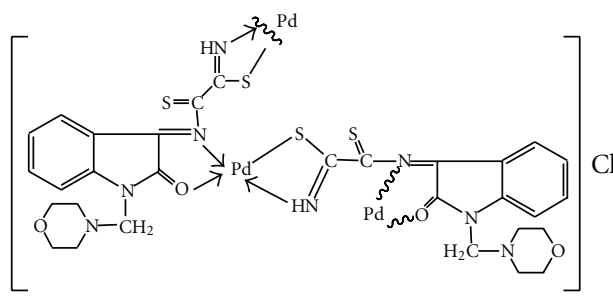

$\mathrm{C}_{6}:\left[\operatorname{Ir}\left(\mathrm{L}_{\mathrm{I}} \mathrm{H}\right)_{2} \mathrm{Cl}_{2}\right] \mathrm{Cl} \cdot(0.5) \mathrm{H}_{2} \mathrm{O}$

$\mathrm{Cl} \cdot 1.5 \mathrm{H}_{2} \mathrm{O}$

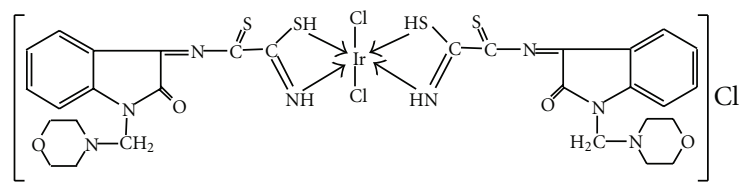

$\mathrm{C}_{7}:\left[\mathrm{Pt}\left(\mathrm{L}_{\mathrm{I}}\right) \mathrm{Cl}_{3}\right] \cdot(0.5) \mathrm{H}_{2} \mathrm{O}$

$\mathrm{C}_{8}:\left[\mathrm{Co}_{2}\left(\mathrm{~L}_{\mathrm{II}} \mathrm{H}\right)_{2}\left(\mathrm{NO}_{3}\right)_{4}\right] \cdot 2 \mathrm{H}_{2} \mathrm{O}$
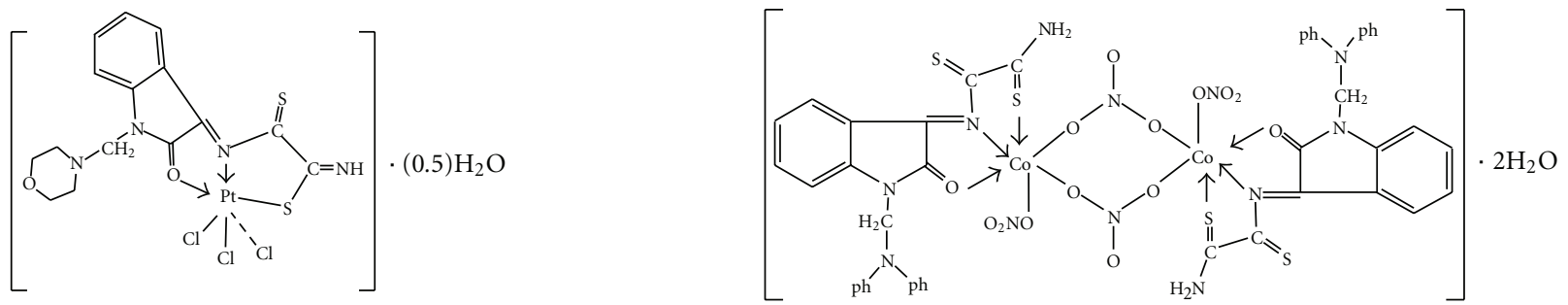

$\mathrm{C}_{9}:\left[\mathrm{Ni}\left(\mathrm{L}_{\mathrm{II}} \mathrm{H}\right)(\mathrm{OAc})_{2}\right] \cdot \mathrm{H}_{2} \mathrm{O}$

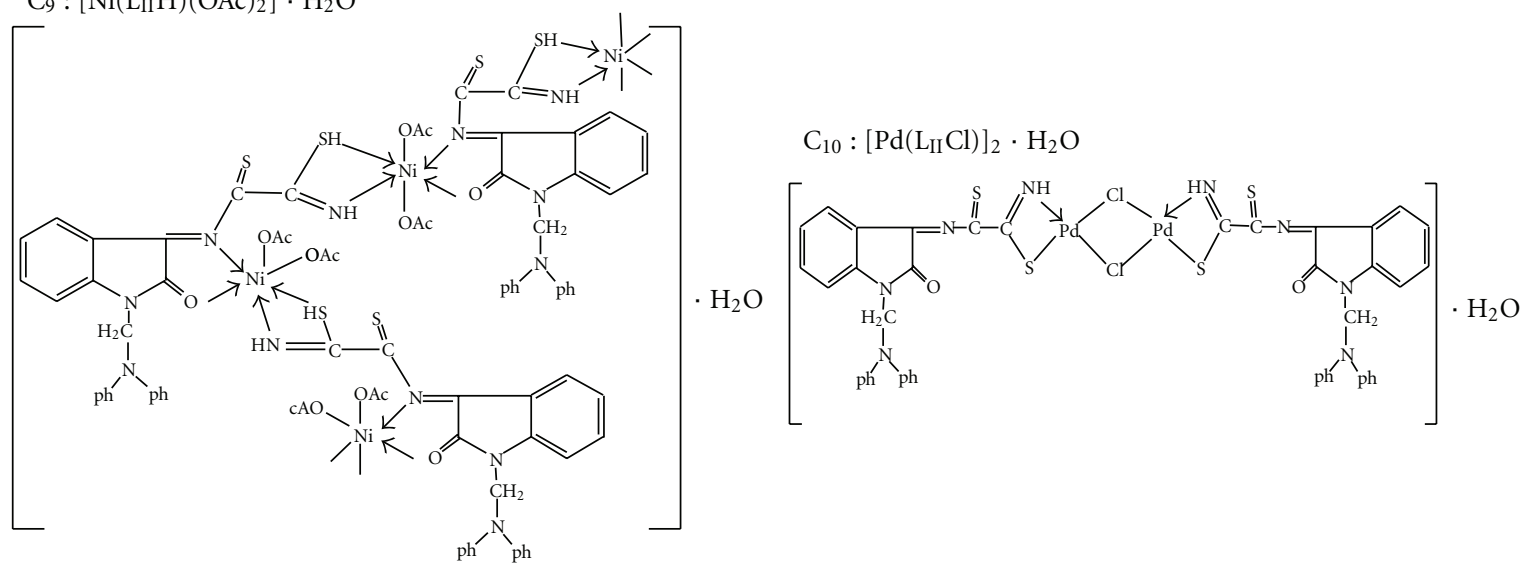

Scheme 3: Continued. 
$\mathrm{C}_{11}:\left[\mathrm{Pt}\left(\mathrm{L}_{\mathrm{II}}\right) \mathrm{Cl}_{2}\left(\mathrm{H}_{2} \mathrm{O}\right)\right] \mathrm{Cl} \cdot \mathrm{H}_{2} \mathrm{O}$

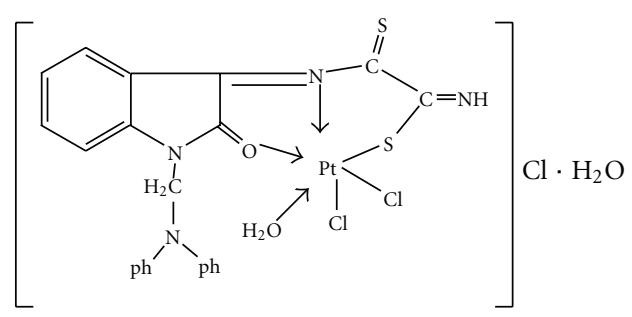

$\mathrm{C}_{12}:\left[\mathrm{Cd}_{2}\left(\mathrm{~L}_{\mathrm{II}}\right)_{2}(\mathrm{OAc})_{2}\left(\mathrm{H}_{2} \mathrm{O}\right)_{4}\right]$

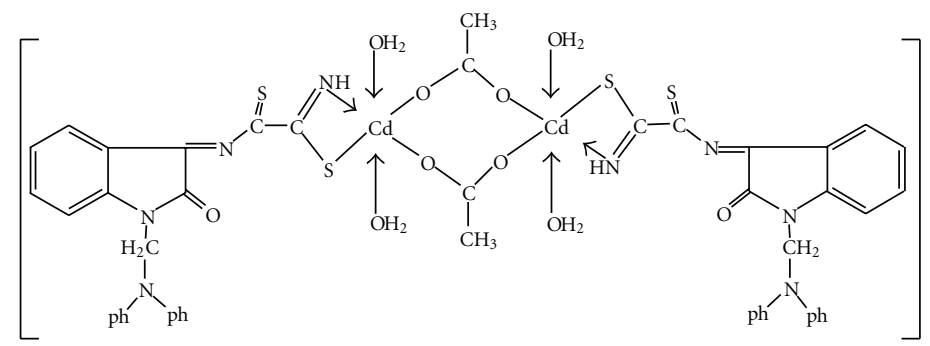

Scheme 3: Suggested structures of Schiff and Mannich base complexes.

TABle 3: Suggested thermal decomposition steps of $\mathrm{C}_{2}$ and $\mathrm{C}_{6}$.

\begin{tabular}{|c|c|c|c|}
\hline $\begin{array}{l}\text { Stable phase (M.wt) } \\
{\left[\mathrm{CoL}_{\mathrm{I}}\left(\mathrm{NO}_{3}\right)_{2}\right] \cdot \mathrm{H}_{2} \mathrm{O}\left(\mathrm{C}_{2}\right)(549.193)}\end{array}$ & $\begin{array}{c}\text { Temp. range of } \\
\text { decomp. at } \mathrm{TG}{ }^{\circ} \mathrm{C}\end{array}$ & Peak temp. at $\mathrm{DTG}{ }^{\circ} \mathrm{C}$ & $\begin{array}{l}\text { \%weight loss found } \\
\text { (calc.) }\end{array}$ \\
\hline $\mathrm{H}_{2} \mathrm{O}$ (Lattice) & $70-120$ & - & $\begin{array}{c}2.91 \\
(3.27)\end{array}$ \\
\hline $\mathrm{NO}_{3}$ & $120-220$ & 200 & $\begin{array}{c}11.62 \\
(11.97)\end{array}$ \\
\hline $\begin{array}{l}\mathrm{C}_{15} \mathrm{~N}_{4} \mathrm{H}_{16} \mathrm{O}_{2} \mathrm{~S}_{2} \\
\mathrm{NO}_{2}\end{array}$ & $220-600$ & - & $\begin{array}{c}71.38 \\
(71.80)\end{array}$ \\
\hline $\mathrm{CoO}$ & - & - & $\begin{array}{c}13.28 \\
(13.64)\end{array}$ \\
\hline \multicolumn{4}{|l|}{$\left[\operatorname{Ir}\left(\mathrm{L}_{\mathrm{I}}\right)_{2} \mathrm{Cl}_{2}\right] \mathrm{Cl} \cdot(0.5) \mathrm{H}_{2} \mathrm{O}\left(\mathrm{C}_{6}\right)(1004.24)$} \\
\hline $\begin{array}{l}0.5 \mathrm{H}_{2} \mathrm{O} \text { (lattice) } \\
\mathrm{C}_{8} \mathrm{~N}_{2} \mathrm{H}_{16} \mathrm{O}_{2}\end{array}$ & $80-250$ & 190 & $\begin{array}{c}17.43 \\
(17.62)\end{array}$ \\
\hline $\begin{array}{l}3 \mathrm{Cl} \\
\mathrm{C}_{9} \mathrm{~N}_{2} \mathrm{H}_{8}\end{array}$ & $250-500$ & 399 & $\begin{array}{c}24.07 \\
(24.94)\end{array}$ \\
\hline $\mathrm{C}_{10} \mathrm{~N}_{3} \mathrm{H}_{6} \mathrm{OS}_{2}$ & $500-700$ & 515 & $\begin{array}{c}24.48 \\
(24.69)\end{array}$ \\
\hline $\mathrm{C}_{2} \mathrm{NS}_{2} \mathrm{H}_{2}$ & $700-830$ & 760 & $\begin{array}{c}13.30 \\
(13.14)\end{array}$ \\
\hline Ir & - & - & $\begin{array}{c}19.83 \\
(19.12)\end{array}$ \\
\hline
\end{tabular}

[50]. According to the above-mentioned data and those of elemental analyses and i.r. spectra, the structures of the metal complexes can be suggested as illustrated in Scheme 3.

\section{Biological Activity}

7.1. Antibacterial Activity. The growth inhibition of the prepared Schiff and Mannich base ligands and some selected metal complexes were studied against three types of pathogenic bacteria, namely, Proteus mirabilis, Escherichia coli, and Staphylococcus aureus by using DMSO as a solvent and the antibiotic Ceftriaxone as a control. Cultures were incubated at $37^{\circ} \mathrm{C}$ for $24 \mathrm{~h}$. The inhibition zones were measured, and results are described in Table 5. The Schiff base precursor $(\mathrm{SBH})$ and $\mathrm{L}_{\mathrm{I}} \mathrm{H}$ were potent against all types of bacteria with the latter being more active than Ceftriaxone, while $\mathrm{L}_{\mathrm{II}} \mathrm{H}$ was inactive. Complexes of $\mathrm{L}_{\mathrm{I}} \mathrm{H}$ with $\mathrm{Co}(\mathrm{II})$, $\mathrm{Ni}(\mathrm{II}), \mathrm{Pd}(\mathrm{II})$, and $\mathrm{Ir}(\mathrm{III})$ ions $\left(\mathrm{C}_{2}, \mathrm{C}_{3}, \mathrm{C}_{5}, \mathrm{C}_{6}\right)$ showed no activity while the $\mathrm{Pt}(\mathrm{IV})$ complex $\left(\mathrm{C}_{7}\right)$ was as active as the original ligand against all types. Among the selected metal complexes of $\mathrm{L}_{\mathrm{II}} \mathrm{H}$, the $\mathrm{Pd}(\mathrm{II})$ complex $\left(\mathrm{C}_{10}\right)$ was highly potent against all bacterial cultures. These results indicate that the degree of growth inhibition is highly dependent on the structure of ligands, metal complexes, and type of metal ion $[51,52]$. Although the inhibition zones of $\mathrm{L}_{\mathrm{I}} \mathrm{H}, \mathrm{C}_{7}$ and $\mathrm{C}_{10}$ were larger than that caused by Ceftriaxone, other categories, like toxicity of these compounds, still have to be studied in detail.

7.2. Cytotoxic Effect. Preliminary cytotoxicity tests of the Schiff base $(\mathrm{SBH})$ and its Mannich base ligands $\left(\mathrm{L}_{\mathrm{I}} \mathrm{H}\right.$ and $\mathrm{L}_{\mathrm{II}} \mathrm{H}$ ) with some selected metal complexes were performed in triplicate against cancer cell line of human epidermoid larynx carcinoma (Hep-2) using concentrations of 62.5, 125, 250 , and $500 \mu \mathrm{g} / \mathrm{mL}$ in DMSO with exposure time of $48 \mathrm{~h}$ using ELISA spectrophotometer. The three organic compounds showed high toxic activities at $125,250,250 \mu \mathrm{g} / \mathrm{mL}$, respectively, causing cell death as was confirmed by the drop 
TABle 4: Electronic spectra, spectral parameters, molar conductivity, and effective magnetic moments $\left(\mu_{\mathrm{eff}}\right)$ of Schiff and Mannich base complexes.

\begin{tabular}{|c|c|c|c|c|c|c|c|}
\hline Comp. no. & $\begin{array}{l}\text { Band positions } \\
\qquad\left(\mathrm{cm}^{-1}\right)\end{array}$ & Assignment & $\begin{array}{c}\mathrm{Dq} / \mathrm{B}^{\prime}\left(\mathrm{B}^{\prime}\right) \\
\left(\mathrm{cm}^{-1}\right)\end{array}$ & $\beta$ & $\begin{array}{c}10 \mathrm{Dq} \\
\left(\mathrm{cm}^{-1}\right)\end{array}$ & $\begin{array}{c}\Omega \\
\left(\mathrm{S} . \mathrm{mol}^{-} . \mathrm{cm}^{2}\right)\end{array}$ & $\mu_{\text {eff }}(\mathrm{BM})$ \\
\hline \multirow{3}{*}{$\begin{array}{l}\mathrm{C}_{1} \\
\mathrm{Mn}(\mathrm{II})\end{array}$} & $v_{1} 17857$ & ${ }^{6} \mathrm{~A}_{1} \mathrm{~g}(\mathrm{~S}) \rightarrow{ }^{4} \mathrm{~T}_{2} \mathrm{~g}(\mathrm{G})$ & \multirow{3}{*}{ - } & \multirow{3}{*}{ - } & \multirow{3}{*}{ - } & \multirow{3}{*}{15.0} & \multirow{3}{*}{5.851} \\
\hline & $v_{2} 25641$ & $\mathrm{~L} \rightarrow \mathrm{M}$ (C.T.) & & & & & \\
\hline & $v_{1} 5352^{(*)}$ & ${ }^{4} \mathrm{~T}_{1} \mathrm{~g} \rightarrow{ }^{4} \mathrm{~T}_{2} \mathrm{~g}$ & & & & & \\
\hline \multirow{3}{*}{$\begin{array}{l}\mathrm{C}_{2} \\
\mathrm{Co}(\mathrm{II})\end{array}$} & $v_{2} 13333$ & ${ }^{4} \mathrm{~T}_{1} \mathrm{~g}(\mathrm{~F}) \rightarrow{ }^{4} \mathrm{~A}_{2} \mathrm{~g}$ & \multirow{3}{*}{$\begin{array}{l}0963 \\
(705)\end{array}$} & \multirow{3}{*}{0.726} & \multirow{3}{*}{6789} & \multirow{3}{*}{6.05} & \multirow{3}{*}{5.446} \\
\hline & $v_{3} 16625$ & ${ }^{4} \mathrm{~T}_{1} \mathrm{~g}(\mathrm{~F}) \rightarrow{ }^{4} \mathrm{~T}_{1} \mathrm{~g}(\mathrm{P})$ & & & & & \\
\hline & $v_{4} 27777$ & $\mathrm{~L} \rightarrow \mathrm{M}$ (C.T.) & & & & & \\
\hline \multirow{4}{*}{$\begin{array}{l}\mathrm{C}_{3} \\
\mathrm{Ni}(\mathrm{II})\end{array}$} & $v_{1} 10204$ & ${ }^{3} \mathrm{~A}_{2} \mathrm{~g} \rightarrow{ }^{3} \mathrm{~T}_{2} \mathrm{~g}^{3}$ & \multirow{4}{*}{$\begin{array}{c}1.65 \\
(619.6)\end{array}$} & \multirow{4}{*}{0.602} & \multirow{4}{*}{10223} & \multirow{4}{*}{186.0} & \multirow{4}{*}{4.18} \\
\hline & $v_{2} 14388$ & $\mathrm{~A}_{2} \mathrm{~g} \rightarrow{ }^{3} \mathrm{~T}_{1} \mathrm{~g}(\mathrm{~F})^{3}$ & & & & & \\
\hline & $v_{3} 21276$ & $\mathrm{~A}_{2} \mathrm{~g} \rightarrow{ }^{3} \mathrm{~T}_{1} \mathrm{~g}(\mathrm{P})$ & & & & & \\
\hline & $v_{1} 11111$ & ${ }^{2} \mathrm{~B}_{1} \mathrm{~g} \rightarrow{ }^{2} \mathrm{~A}_{1} \mathrm{~g}$ & & & & & \\
\hline \multirow{3}{*}{$\begin{array}{l}\mathrm{C}_{4} \\
\mathrm{Cu}(\mathrm{II})\end{array}$} & $v_{2} 16667$ & ${ }^{2} \mathrm{~B}_{1} \mathrm{~g} \rightarrow{ }^{2} \mathrm{~B}_{2} \mathrm{~g}$ & \multirow[t]{3}{*}{-} & \multirow[t]{3}{*}{-} & \multirow[t]{3}{*}{ - } & \multirow[t]{3}{*}{282.0} & \multirow[t]{3}{*}{2.51} \\
\hline & $v_{3} 22222$ & ${ }^{2} \mathrm{~B}_{1} \mathrm{~g} \rightarrow{ }^{2} \mathrm{Eg}$ & & & & & \\
\hline & $v_{4} 28571$ & $\mathrm{~L} \rightarrow \mathrm{M}$ (C.T.) & & & & & \\
\hline \multirow{2}{*}{$\begin{array}{l}\mathrm{C}_{5} \\
\mathrm{Pd}(\mathrm{II})\end{array}$} & $\nu_{1} 16393$ & ${ }^{1} \mathrm{~A}_{1} \mathrm{~g} \rightarrow{ }^{1} \mathrm{~A}_{2} \mathrm{~g}$ & \multirow{2}{*}{-} & \multirow{2}{*}{-} & - & 77.0 & Diamag. \\
\hline & $v_{2} 21276$ & ${ }^{1} \mathrm{~A}_{1} \mathrm{~g} \rightarrow{ }^{1} \mathrm{~B}_{1} \mathrm{~g}$ & & & & & \\
\hline & $v_{1} 14705$ & ${ }^{1} \mathrm{~A}_{1} \mathrm{~g} \rightarrow{ }^{3} \mathrm{~T}_{1} \mathrm{~g}$ & & & & & \\
\hline $\begin{array}{l}\mathrm{C}_{6} \\
\operatorname{Ir}(\mathrm{III})\end{array}$ & $v_{2} 18518$ & ${ }^{1} \mathrm{~A}_{1} \mathrm{~g} \rightarrow{ }^{1} \mathrm{~T}_{2} \mathrm{~g}$ & - & - & - & 90.0 & Diamag. \\
\hline & $v_{3} 22222$ & $\mathrm{~L} \rightarrow \mathrm{M}$ (C.T.) & & & & & \\
\hline & $v_{1} 15625$ & ${ }^{1} \mathrm{~A}_{1} \mathrm{~g} \rightarrow{ }^{3} \mathrm{~T}_{1} \mathrm{~g}$ & & & & & \\
\hline $\begin{array}{l}\mathrm{C}_{7} \\
\mathrm{Pt}(\mathrm{IV})\end{array}$ & $v_{2} 21276$ & ${ }^{1} \mathrm{~A}_{1} \mathrm{~g} \rightarrow{ }^{3} \mathrm{~T}_{2} \mathrm{~g}$ & - & - & - & 15.0 & Diamag. \\
\hline & $v_{3} 23255$ & $\mathrm{~L} \rightarrow \mathrm{M}$ (C.T.) & & & & & \\
\hline & $v_{1} 5471^{(*)}$ & ${ }^{4} \mathrm{~T}_{1} \mathrm{~g} \rightarrow{ }^{4} \mathrm{~T}_{2} \mathrm{~g}$ & & & & & \\
\hline $\mathrm{C}_{8}$ & $v_{2} 10989$ & ${ }^{4} \mathrm{~T}_{1} \mathrm{~g} \rightarrow{ }^{4} \mathrm{~A}_{2} \mathrm{~g}$ & $\begin{array}{c}0.843 \\
(76261)\end{array}$ & 0785 & 6430 & 18.0 & 4.617 \\
\hline & $v_{3} 15795$ & ${ }^{4} \mathrm{~T}_{1} \mathrm{~g}(\mathrm{~F}) \rightarrow{ }^{4} \mathrm{~T}_{1} \mathrm{~g}(\mathrm{P})$ & & & & & \\
\hline & $v_{4} 26315$ & $\mathrm{~L} \rightarrow \mathrm{M}$ (C.T.) & & & & & \\
\hline & $v_{1} 10172$ & ${ }^{3} \mathrm{~A}_{2} \mathrm{~g} \rightarrow{ }^{3} \mathrm{~T}_{2} \mathrm{~g}$ & & & & & \\
\hline $\begin{array}{l}\mathrm{C}_{9} \\
\mathrm{Ni}(\mathrm{II})\end{array}$ & $v_{2} 14845$ & ${ }^{3} \mathrm{~A}_{2} \mathrm{~g} \rightarrow{ }^{3} \mathrm{~T}_{1} \mathrm{~g}(\mathrm{~F})$ & 1.667 & 0594 & 10200 & 20.5 & 4.251 \\
\hline & $v_{3} 22727$ & ${ }^{3} \mathrm{~A}_{1} \mathrm{~g} \rightarrow{ }^{3} \mathrm{~T}_{1} \mathrm{~g}(\mathrm{P})$ & & & & & \\
\hline & $v_{4} 27027$ & $\mathrm{~L} \rightarrow \mathrm{M}$ (C.T.) & & & & & \\
\hline & $v_{1} 16025$ & ${ }^{1} \mathrm{~A}_{1} \mathrm{~g} \rightarrow{ }^{1} \mathrm{~A}_{2} \mathrm{~g}$ & & & & & \\
\hline $\begin{array}{l}\mathrm{Cl} \\
\mathrm{Pd}(\mathrm{II})\end{array}$ & $v_{2} 21739$ & ${ }^{1} \mathrm{~A}_{1} \mathrm{~g} \rightarrow{ }^{1} \mathrm{~B}_{1} \mathrm{~g}$ & - & - & - & 9.0 & Diamag. \\
\hline & $v_{3} 26315$ & ${ }^{1} \mathrm{~A}_{1} \mathrm{~g} \rightarrow{ }^{1} \mathrm{Eg}$ & & & & & \\
\hline $\mathrm{C}_{11}$ & $v_{1} 15908$ & ${ }^{1} \mathrm{~A}_{1} \mathrm{~g} \rightarrow{ }^{3} \mathrm{~T}_{1} \mathrm{~g}$ & - & - & - & 73.0 & Diamag. \\
\hline $\operatorname{Pt}(\mathrm{IV})$ & $v_{2} 27027$ & $\mathrm{~L} \rightarrow \mathrm{M}$ (C.T.) & & & & & \\
\hline $\mathrm{C}_{12}$ & $v_{1} 27777$ & $\mathrm{~L} \rightarrow \mathrm{M}$ (C.T.) & & & & 8.00 & Diamag. \\
\hline $\mathrm{Cd}(11)$ & $v_{2} 32786$ & Intralig $\pi \rightarrow \pi^{*}$ & & & & & \\
\hline
\end{tabular}

${ }^{*}$ Calculated. 
TABle 5: Antibacterial activities of the Schiff and Mannich bases and some selected metal complexes showing inhibition zones in diameters $(\mathrm{mm})$.

\begin{tabular}{lccccccc}
\hline Entry & Compound & \multicolumn{2}{c}{ Proteus mirabilis } & \multicolumn{2}{c}{ Escherichia coli } & \multicolumn{2}{c}{ Staphylococcus aureus } \\
\hline 1 & $\mathrm{SBH}$ & 19 & ++ & 30 & +++ & 29 & +++ \\
2 & $\mathrm{~L}$ & 32 & ++++ & 48 & +++++ & 43 & +++++ \\
3 & $\mathrm{~L}(\mathrm{II})\left(\mathrm{C}_{2}\right)$ & - & - & - & - & - & - \\
4 & $\mathrm{Pd}(\mathrm{II})\left(\mathbf{C}_{5}\right)$ & - & - & 8 & - & 9 & - \\
5 & $\mathrm{Ir}(\mathrm{III})\left(\mathrm{C}_{6}\right)$ & - & - & 10 & - & 9 & - \\
6 & $\mathrm{Pt}(\mathrm{IV})\left(\mathbf{C}_{7}\right)$ & 38 & +++++ & 39 & +++++ & 44 & ++++ \\
7 & $\mathrm{~L}$ & 9 & - & 9 & - & 12 & - \\
8 & $\mathrm{~L}(\mathrm{II})\left(\mathrm{C}_{8}\right)$ & 9 & - & 8 & - & 15 & + \\
9 & $\mathrm{Pd}(\mathrm{II})\left(\mathrm{C}_{10}\right)$ & 38 & +++++ & 39 & +++++ & 44 & +++++ \\
10 & $\mathrm{Cd}(\mathrm{II})\left(\mathbf{C}_{12}\right)$ & 9 & - & 8 & - & 15 & + \\
11 & $\operatorname{ceftriaxone}$ & 28 & +++ & 30 & +++ & 36 & ++++ \\
\hline
\end{tabular}

in optical absorbance of NR in the treated cells compared with the controls which refers to complete disruption of cell functions [53]. The cytotoxic effect of metal complexes of $\mathrm{L}_{\mathrm{I}} \mathrm{H}$ was found to increase in the order of $\mathrm{Pt}(\mathrm{IV})<\mathrm{Pd}(\mathrm{II})<<$ $\operatorname{Ir}(\mathrm{III})$ as is shown in Figure 9. The $\mathrm{Pt}(\mathrm{IV})$ complex $\left(\mathrm{C}_{7}\right)$ was much less active than the parent ligand, and its performance was found to decrease with concentration that it was totally inactive at $500 \mu \mathrm{g} / \mathrm{mL}$.

The $\mathrm{Pd}(\mathrm{II})$ complex $\left(\mathrm{C}_{5}\right)$ followed the same trend of concentration as the $\mathrm{Pt}(\mathrm{IV})$ complex but it was toxic enough to cause cell death. The $\operatorname{Ir}(\mathrm{III})$ complex $\left(\mathrm{C}_{6}\right)$ was exceptionally active, and its cytotoxic activity was found to increase with concentration. Figure 10 illustrates the difference in dye distribution in the tissue culture sections of Hep-2 before and after treatment with this complex in comparison with the control. Both the $\mathrm{Pd}(\mathrm{II})$ and $\mathrm{Cd}(\mathrm{II})$ complexes of $\mathrm{L}_{\mathrm{II}} \mathrm{H}$ $\left(\mathrm{C}_{10}\right.$ and $\left.\mathrm{C}_{12}\right)$ were less toxic than the parent ligand, and their activity slightly increased with concentration. The $\mathrm{Cd}(\mathrm{II})$ complex $\left(\mathrm{C}_{12}\right)$ caused $30-60 \%$ decrease of ligand activity. The complex was similarly inactive against growth of the three bacterial cultures although $\mathrm{Cd}^{++}$ion is well known as an environmental carcinogen at very low concentrations in human and animals [54]. This indicates that the toxicity of $\mathrm{Cd}^{++}$ion can be decreased on complexation with some ligands.

The present study describes a narrow scope of the cytotoxic activity of the studied compounds. Extension of this study, in future work to involve other cancer cell lines and other metal complexes, using normal human cell lines as control, may reveal more important data.

\section{Conclusions}

Condensation of dithiooxamide with isatin or its N-Mannich bases occurred from one amino end of the compound which allowed for tautomerism of the resulted compound in solutions as was confirmed by ${ }^{1}$ H.n.m.r spectrum of the product and from the IR spectra of some of its coordination compounds. The potent chelating behavior of the two new
Mannich and Schiff bases led to the formation of bi- and polynuclear metal complexes. The preliminary study of biological activity showed some controversy in performance between bacterial growth inhibition and cytotoxic activities against Hep-2 cell line. The $\operatorname{Ir}(\mathrm{III})$ complex of $\mathrm{L}_{\mathrm{I}} \mathrm{H}$ which showed the highest cytotoxic effect was almost inactive against bacterial growth.

\section{References}

[1] S. N. Pandeya, S. Smitha, M. Jyoti, and S. K. Sridhar, "Biological activities of isatin and its derivatives," Acta Pharmaceutica, vol. 55, no. 1, pp. 27-46, 2005.

[2] S. K. Sridhar, S. N. Pandeya, J. P. Stables, and A. Ramesh, "Anticonvulsant activity of hydrazones, Schiff and Mannich bases of isatin derivatives," European Journal of Pharmaceutical Sciences, vol. 16, no. 3, pp. 129-132, 2002.

[3] S. K. Sridhar, M. Saravanan, and A. Ramesh, "Synthesis and antibacterial screening of hydrazones, Schiff and Mannich bases of isatin derivatives," European Journal of Medicinal Chemistry, vol. 36, no. 7-8, pp. 615-625, 2001.

[4] R. W. Daisley and V. K. Shah, "Synthesis and antibacterial activity of some 5-nitro-3-phenyliminoindol-2(3H)-ones and their N-mannich bases," Journal of Pharmaceutical Sciences, vol. 73, no. 3, pp. 407-408, 1984.

[5] J. Borysiewicz and B. Lucka-Sobstel, "The effect of certain Mannich $\mathrm{N}$-bases, derivatives of isatin beta-thiosemicarbazone, on the replication of vaccinia virus in in vitro studies," Acta Microbiologica Polonica, vol. 27, no. 2, pp. 111-121, 1978.

[6] S. N. Pandeya, D. Sriram, G. Nath, and E. De Clercq, "Synthesis and antimicrobial activity of Schiff and Mannich bases of isatin and its derivatives with pyrimidine," Farmaco, vol. 54, no. 9, pp. 624-628, 1999.

[7] D. Maysinger, M. Movrin, and M. M. Saric, "Structural analogues of isatin and their antimicrobial activity," Pharmazie, vol. 35, no. 1, pp. 14-16, 1980.

[8] S. N. Pandeya, D. Sriram, E. DE. Clercq, C. Pannecouque, and M. Witvrouw, "Anti-HIV activity of some Mannich bases of Isatin derivatives," Indian Journal of Pharmaceutical Sciences, vol. 60, no. 4, pp. 207-212, 1998. 
[9] S. K. Sridhar, S. N. Pandeya, and E. De Clercq, "Synthesis and anti-HIV activity of some isatin derivatives," Bollettino Chimico Farmaceutico, vol. 140, no. 5, pp. 302-305, 2001.

[10] Q. Y. Ye, Y. Nakano, G. R. Frauenhoff, D. R. Whitcomb, F. Takusagawa, and D. H. Busch, "Tetradentate dithiooxamide ligands and their nickel complexes. Synthesis, characterization, and crystal structure of a mononuclear neutral complex, $\mathrm{Ni}\left(\mathrm{c}-\mathrm{C}_{5} \mathrm{H}_{9}\right) \mathrm{NHC}(\mathrm{S}) \mathrm{N}\left(\mathrm{CH}_{2}\right)_{2} \mathrm{NC}(\mathrm{S}) \mathrm{C}(\mathrm{S}) \mathrm{NH}\left(\mathrm{c}-\mathrm{C}_{5} \mathrm{H}_{9}\right)$," Inorganic Chemistry, vol. 30, no. 7, pp. 1503-1510, 1991.

[11] P. J. Werkman, A. Schasfoort, R. H. Wieringa, and A. J. Schouten, "Langmuir-Blodgett films of a polymerisable N,N'disubstituted dithiooxamide coordination compound," Thin Solid Films, vol. 323, no. 1-2, pp. 243-250, 1998.

[12] M. R. Green, N. Jubran, B. E. Bursten, and D. H. Busch, "Transition-metal complexes of dithiooxamide ligands. Vibrational fine structure in the electronic spectra of symmetrically $\mathrm{N}, \mathrm{N}$ '-disubstituted dithiooxamides and their divalent nickel ion complexes," Inorganic Chemistry, vol. 26, no. 14, pp. 23262332, 1987.

[13] J. A. Lekstrom and R. D. Koons, "Copper and nickel detection on gunshot targets by dithiooxamide test," Journal of Forensic Sciences, vol. 31, no. 4, pp. 1283-1291, 1986.

[14] A. Castiñeiras, M. C. F. Vidal, J. Romero et al., "Synthesis, characterization, and magnetic behaviour of dinuclear nickel(II) complexes of $\mathrm{N}, \mathrm{N}^{\prime}$-substituted dithiooxamides derived from $\alpha$-amino acids," Zeitschrift fur Anorganische und Allgemeine Chemie, vol. 627, no. 7, pp. 1553-1559, 2001.

[15] L. Stoicescu, M. Negoiu, R. Geogescu, and T. Rosu, 'Pd(II), Pt(II), and $\mathrm{Cu}(\mathrm{II})$ complexes of N,N'-bis(methoxyylethyl)ethandithioamide synthesis and spectroscopic studies," in Proceedings of the 12th Romanian Conference of Chemistry and Chemical Engineering, Bucharest, Romania, December 2001.

[16] M. Jansersca and B. Stojceva, "Synthesis of Isatin N-Mannich Bases," Glas Hem Technol Make donya, vol. 2, no. 1-2, pp. 53 58, 1977.

[17] A. I. Vogel, A Text Book of Practical Organic Chemistry, Longmans, London, UK, 3rd edition, 1972.

[18] E. G. Rochow, Inorganic Synthesis, vol. 4, McGraw-Hill, New York, NY, USA, 1960.

[19] J. Catt and M. L. Seak, Inorganic Synthesis, vol. 5, Wiley, New York, NY, USA, 1957.

[20] L. H. Kalbus and G. E. Kalbus, "Potentiometric determination of silver with dithiooxamide," Analytica Chimica Acta, vol. 39, pp. 335-340, 1967.

[21] O. V. Mikhailov and A. I. Khamitova, "Mild template synthesis of (2,8-dithio-3,7-diaza-5-oxanonanedithioamido1,9)aquohydroxocobalt(III) in the $\mathrm{KCoFe}(\mathrm{CN})_{6}$ gelatinimmobilized matrix systems," Russian Journal of Coordination Chemistry, vol. 24, no. 11, pp. 807-810, 1998.

[22] E. G. Mesropyan, G. B. Ambartsumyan, A. A. Avetisyan, M. G. Sarkisyan, and G. S. Amazaspyan, "Synthesis of isatin and 5-bromoisatin derivatives," Russian Journal of Organic Chemistry, vol. 37, no. 10, pp. 1476-1477, 2001.

[23] R. C. Elderfield and J. R. Wood, "Synthesis of potential anticancer agents. XV. Nitrogen mustards from indole derivatives," Journal of Organic Chemistry, vol. 27, no. 7, pp. 2463-2465, 1962.

[24] S. N. Pandeya, D. Sriram, G. Nath, and E. De Clercq, "Synthesis, antibacterial, antifungal and anti-HIV activities of norfloxacin Mannich bases," European Journal of Medicinal Chemistry, vol. 35, no. 2, pp. 249-255, 2000.
[25] M. C. Pirrung and S. V. Pansare, "Trityl isothiocyanate support for solid-phase synthesis," Journal of Combinatorial Chemistry, vol. 3, no. 1, pp. 90-96, 2001.

[26] N. P. Peet and R. J. Barbuch, "Mass spectral fragmentation and rearrangement of isatin derivatives," Organic Mass Spectrometry, vol. 19, no. 4, pp. 171-175, 1984.

[27] P. W. West and L. R. M. Pitombo, "Microdetermination of copper using dithiooxamide crayons and the ring-oven technique," Analytica Chimica Acta, vol. 37, pp. 374-378, 1967.

[28] N. Usami, K. Kitahara, S. Ishikura, M. Nagano, S. Sakai, and A. Hara, "Characterization of a major form of human isatin reductase and the reduced metabolite," European Journal of Biochemistry, vol. 268, no. 22, pp. 5755-5763, 2001.

[29] M. C. F. Vidal, I. Lens, A. Castiñeiras, A. Matilla Hernández, J. M. Tercero Moreno, and J. Niclós-Gutiérrez, "N,N' substituted dithiooxamides derived from alkyl- $\alpha$-amino acids or from glycylglycine: acid dissociation properties in aqueous solution and crystal and molecular structures of N,N' bis(carboxymethyl) dithiooxamide (GLYDTO) and N,N' bis(1-carboxyethyl) dithiooxamide (ALADTO)," Polyhedron, vol. 18 , no. 25, pp. 3313-3319, 1999.

[30] M. Unger, W. Jacobsen, U. Holzgrabe, and L. Z. Benet, "Quantitative liquid chromatography-mass spectrometry determination of isatin in urine using automated on-line extraction," Journal of Chromatography B, vol. 767, no. 2, pp. 245-253, 2002.

[31] D. Wang, Y.-D. Shang, F. Quin, L. Fang, and P. Grong, "Synthesis and in Vitro Antivaral Activities of Some New 2-Arylthiomethyl-4-tertiarylaminomethyl substituted derivatives of 6-Bromo-3-ethoxycarbonyl-5-hydroxyindoles," Chinese Chemical Letters, vol. 15, no. 1, pp. 19-22, 2004.

[32] J. B. Jensen, H. Egsgaard, H. Van Onckelen, and B. U. Jochimsen, "Catabolism of indole-3-acetic acid and 4- and 5-chloroindole-3-acetic acid in Bradyrhizobium japonicum," Journal of Bacteriology, vol. 177, no. 20, pp. 5762-5766, 1995.

[33] M. Yoneda, K. Tsujimoto, M. Ohashi, M. Shiratsuchi, and Y. Ohkawa, "Structures of $[\mathrm{M}-44]^{+}$ions in the electron impact and fast atom bombardment mass spectra of the bblocker nipradilol with nitrate ester group," Organic Mass Spectrometry, vol. 25, no. 3, pp. 146-150, 1990.

[34] V. Yaylayan, J. R. J. Paré, R. Laing, and P. Sporns, "Formation of $\beta$-carboline from 1-[1'-carboxy-2'-indole-3-ylethyl)amino]-1-deoxy-D-fructose under electron impact conditions," Organic Mass Spectrometry, vol. 25, no. 2, pp. 141$145,1990$.

[35] R. M. Silverstein and F. X. Webster, Spectrometric Identification of Organic Compounds, John Wiley and Sons, New York, NY, USA, 6th edition, 1997.

[36] N. Raman, S. Ravichandran, and C. Thangaraja, "Copper(II), cobalt(II), nickel(II) and zinc(II) complexes of Schiff base derived from benzil-2,4-dinitrophenylhydrazone with aniline," Journal of Chemical Sciences, vol. 116, no. 4, pp. 215-219, 2004.

[37] M. Singh and R. Nayan, "Synthesis and characterization of nickel(II) complexes with some tetraaza macrocyclic ligands," Indian Journal of Chemistry. Section A, vol. 35, no. 3, pp. 239242, 1996.

[38] J. R. Allan, J. G. Bonner, A. R. Werninck, H. J. Bowley, and D. L. Gerrard, "Thermal studies on itaconic acid compounds of some transition metal ions," Thermochimica Acta, vol. 122, no. 2, pp. 295-303, 1987.

[39] G. L. Van De Cappelle and M. A. Herman, "Dissociation constants of n,n'-bis(2-carboxyethyl)dithiooxamide," Analytica Chimica Acta, vol. 43, pp. 89-94, 1968. 
[40] H. O. Desseyn, W. A. Jacob, and M. A. Herman, "Infrared absorption spectra of complexes of dithio-oxamides," Spectrochimica Acta Part A, vol. 25, no. 10, pp. 1685-1692, 1969.

[41] H. C. Hofmans, H. O. Desseyn, R. A. Dommisse, P. Van Nuffel, and A. T. H. Lenstra, "Determination of the crystal structure and the spectroscopic data of $\operatorname{Pd}\left(\mathrm{N}, \mathrm{N}^{\prime}\right.$ -dicyclopentyldithiooxamide)," Transition Metal Chemistry, vol. 9, no. 6, pp. 213-217, 1984.

[42] K. Nakamato, Infrared and Ramman Spectra of Inorganic and Coordination Compounds, John Wiley and Sons, New York, NY, USA, 5th edition, 1997.

[43] X. Weimiad, W. Shurong, and L. Zhiyong, "Synthesis of rare earth coordination compounds of salicylalde-hyde- $\beta$-alanine schiff base and their thermal behaviours I," Thermochimica Acta, vol. 133, pp. 377-382, 1988.

[44] C. Duval, Inorganic Thermogravimetric Analysis, Elsevier, London, UK, 2nd edition, 1963.

[45] J. R. Allan, A. Renton, W. E. Smith, D. L. Gerrard, and J. Birnie, "Thermal studies on pyridine-3,4-dicarboxylic acid compounds of cobalt, nickel and copper," Thermochimica Acta, vol. 161, no. 1, pp. 111-118, 1990.

[46] D. Sutton, Electronic Spectra of Transition Metal Complexes, McGraw-Hill, New York, NY, USA, 1968.

[47] A. B. . Lever, Inorganic Electronic Spectroscopy, Elsevier, Amsterdam, The Netherlands, 1968.

[48] B. N. Figgis, Introduction to Ligand Fields, John Wiely and Sons, New York, NY, USA, 1966.

[49] K. Bruger, Coordination Chemistry, Experimental Methods, Butterworth, London, UK, 1967.

[50] W. J. Geary, "The use of conductivity measurements in organic solvents for the characterisation of coordination compounds," Coordination Chemistry Reviews, vol. 7, no. 1, pp. 81-122, 1971.

[51] A. A. Khandar, K. Nejati, and Z. Rezvani, "Syntheses, characterization and study of the use of cobalt (II) SchiffBase complexes as catalysts for the oxidation of styrene by molecular oxygen," Molecules, vol. 10, no. 1, pp. 302-311, 2005.

[52] N. Nawar, M. A. Khattab, M. M. Bekheit, and A. H. El-Kaddah, "Synthesis and spectral studies of manganese(II), cobalt(II), nickel(II), copper(II), zinc(II), cadmium(II) and mercury(II) complexes of 4-oxo-4H-1-benzopyran-3-carboxaldehyde hydrazone derivatives," Indian Journal of Chemistry. Section A, vol. 35, no. 4, pp. 308-312, 1996.

[53] A. Ravid, D. Rocker, A. Machlenkin et al., "1,25-Dihydroxyvitamin D enhances the susceptibility of breast cancer cells to doxorubicin-induced oxidative damage," Cancer Research, vol. 59, no. 4, pp. 862-867, 1999.

[54] S. S. Roy, S. Mukherjee, S. Mukhopadhyay, and S. K. Das, "Differential effect of cadmium on cholinephosphotransferase activity in normal and cancerous human mammary epithelial cell lines," Molecular Cancer Therapeutics, vol. 3, no. 2, pp. 199-204, 2004. 


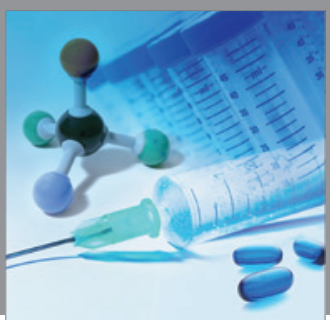

International Journal of

Medicinal Chemistry

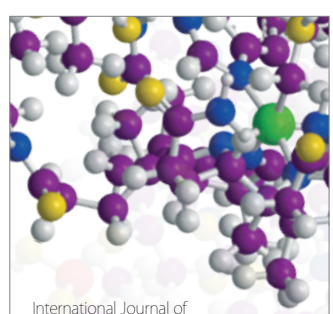

Carbohydrate Chemistry

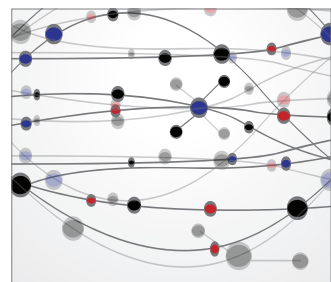

The Scientific World Journal
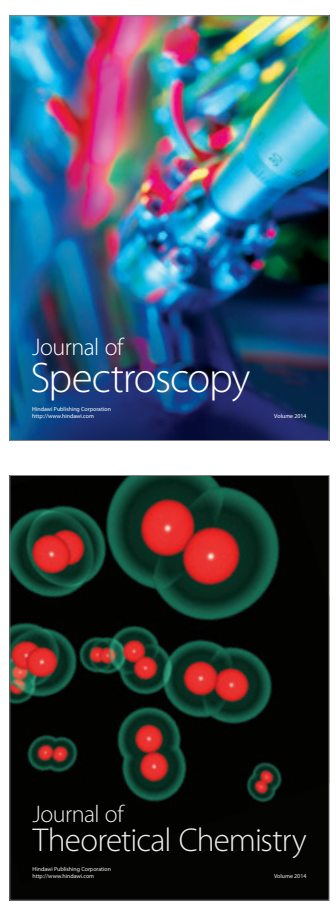
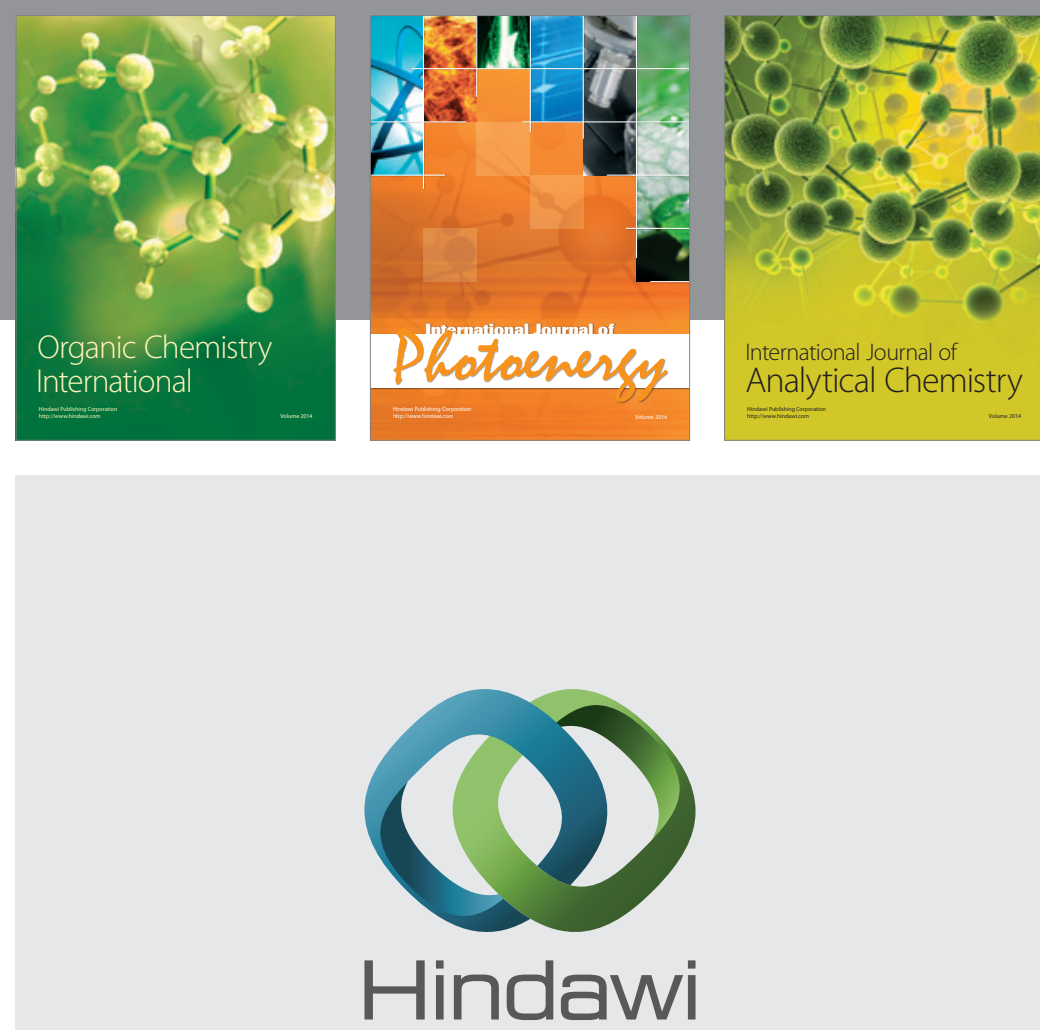

Submit your manuscripts at

http://www.hindawi.com
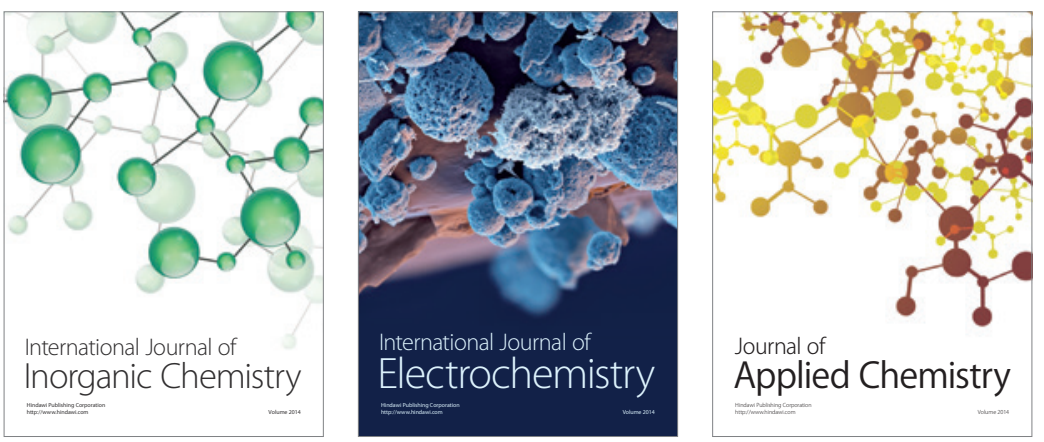

Journal of

Applied Chemistry
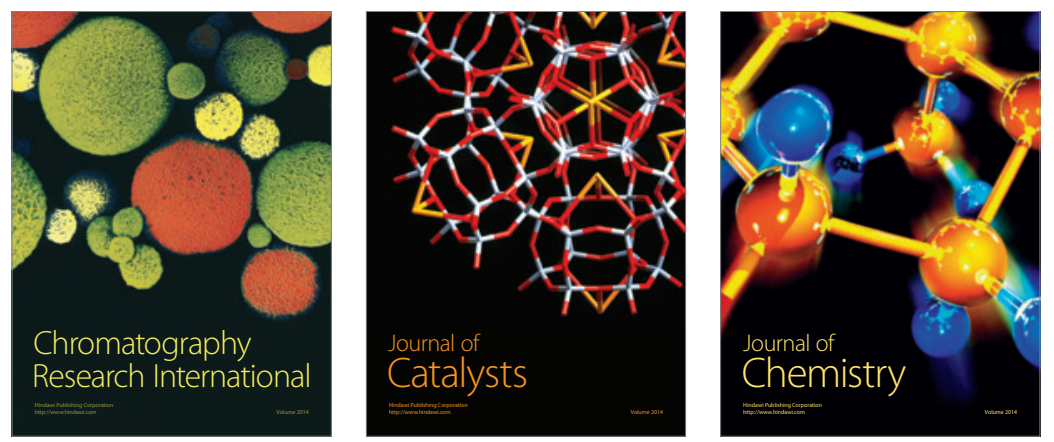
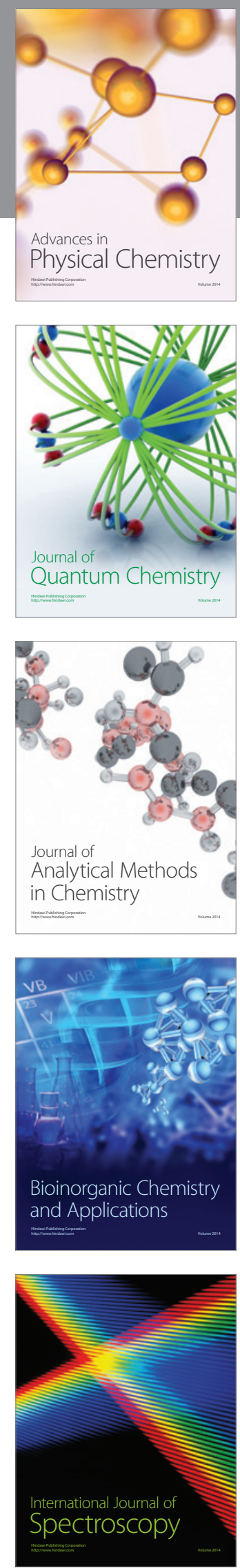